c or the second year in a row, the University of Alberta was represented at the Society of American Foresters (SAF) annual conference in Pittsburgh, Pennsylvania. In addition to attending the conference and competing in the Quiz Bowl, students participated in tours of the temperate forest of Pennsylvania. This student-lead initiative was made possible with the help of the University of Alberta's Department of Renewable Resources in addition to support from other sponsors.

Preparation for the conference began early in 2006. Ten energetic students from forestry and forest business management programs, as well as John Spence and Alex Drummond, committed themselves to raising funds to attend the conference. Fundraising events were held to promote interest and raise funds for the trip. Tryouts were held to determine who was going to sit on the Quiz Bowl Team, as only four students and an alternate could participate.

In the end, the Team consisted of Eiry Spence (captain), Derek Bakker, Jeron Snively and Athena Andritz. Ben Poltorak was the alternate. The group advanced to the second round in Pitts- burgh and was narrowly defeated in the overtime showdown. Quiz topics included dendrology, silviculture, fire suppression, entomology and pathology, and American forest history and policy. This year's team improved over the previous year with the expectation that next year's team will do even better.

John Spence, a former resident of Pennsylvania and Chair of the Department of Renewable Resources, undertook to schedule field tours into the Allegheny Highlands of western Pennsylvania. The first evening was spent along the Clarion River, designated a U.S. Wild and Scenic River in 1996. The next morning we woke to a local tradition of catfish and eggs in the heart of the cathedral forest. Next was a stop at the Highland Forest Resources cherry sawmill in Muzette, which produces specialty lumber for furniture production. This provided significant contrast to the production-based lumber mills of Western Canada. Our third stop was the Allegheny National Forest where we observed shelterwood systems and integrated land management. The final stop was in Kane, the "Black Cherry Capital of the World," where we learned about methods of hardwood silviculture and harvesting on private land.

Day 2 began at Johnsonburg at the oldest continuously operating paper mill in the United States. Weyerhaeuser presently owns it. The tour ended at Clarion Boards Ltd. where we shown the high tech business of MDF production. The two-day field tour was an excellent opportunity to observe forestry in the Eastern United States and provided us with an outstanding educational experience.

The next three days were spent at the SAF conference in Pittsburgh. Students were free to take in the numerous sessions, ranging from forest management, agroforestry, forest certification, economics, to watershed management and land reclamation. It was a good opportunity to share experiences and have discussions with forest practitioners from all around the U.S.

The Quiz Bowl Team would like to thank the generosity of the various sponsors: the University's Sustainable Resources Department, Alberta Sustainable Resource Development, Alberta-Pacific, Weyerhaeuser, the College of Professional Foresters, the Cana-

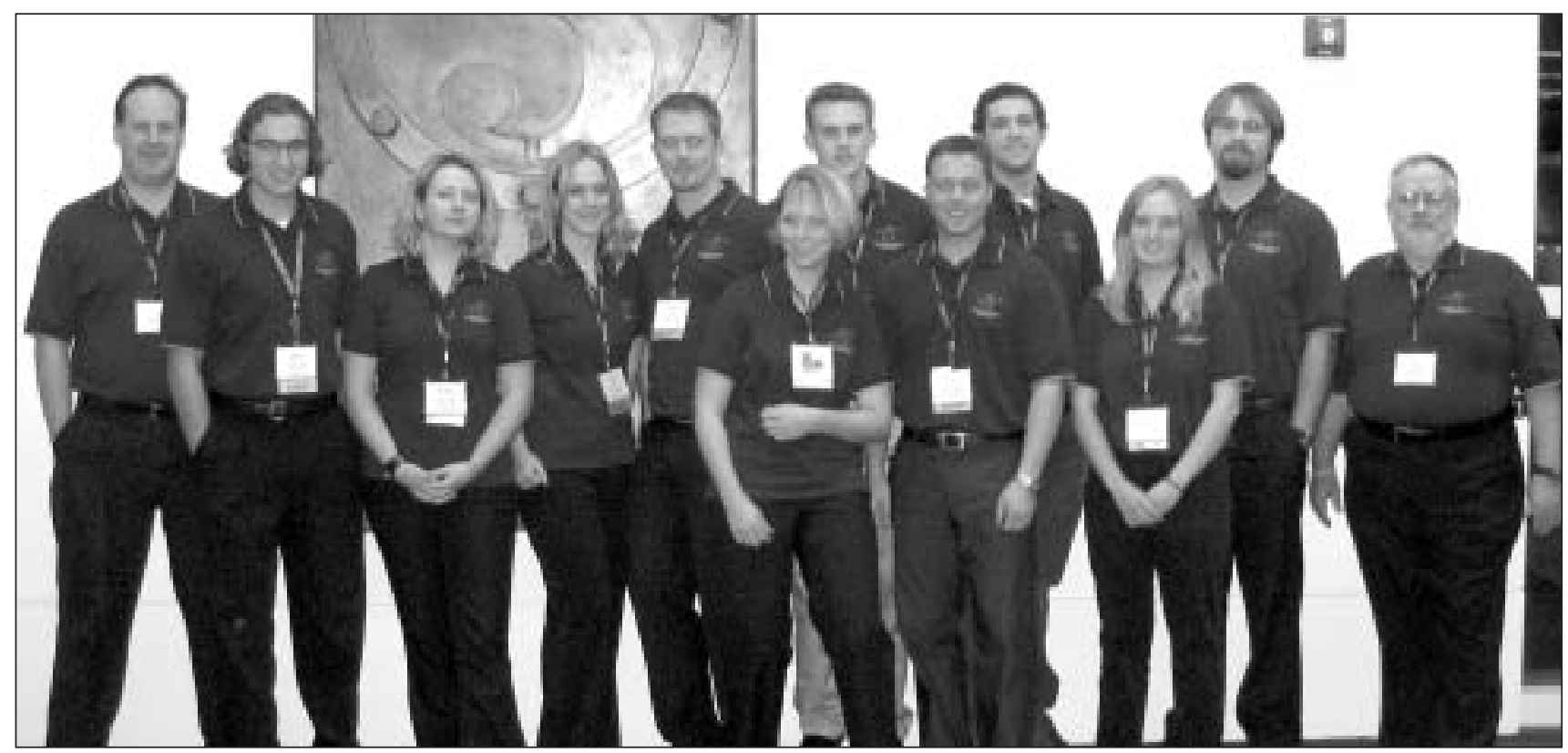

The 2006 Quiz Bowl Team (left to right): Alex Drummond, Derek Bakker, Athena Andritz, Rae Lett, Jeron Snively, Amanda Avery, Matt Denney, Chad Gardeski, Dan LaFleur, Eiry Spence, Ben Poltorak and John Spence. 


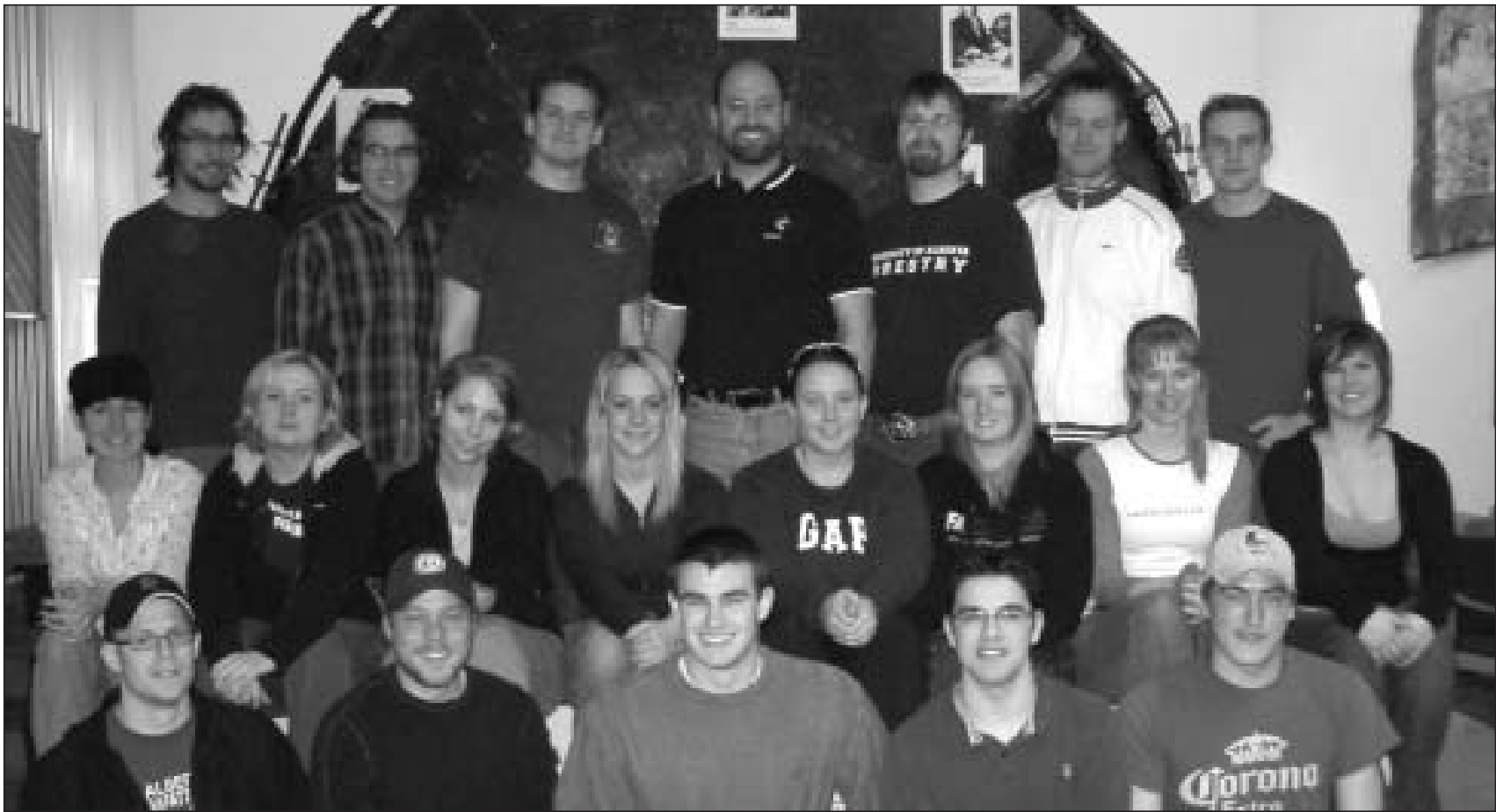

The Class of 2007: Athena Andritz, Dana Archibald, Amanda Avery, Derek Bakker, Ashley Barnhardt, Elizabeth Boschma, Matthew Denney, Chad Gardeski, Garth Giroux, Ryan Good, Peter Letawsky, Rae Lett, Ben Poltorak, Mark Ramaekers, Cameron, Rollins, Pamela Slaney, Eiry Spence, David Springer, Brandon Taylor, Janine Tutt

dian Institute of Forestry, Alberta Forest Products Associations, Timberline, and Silvicom.

\section{Other News}

Professor Jim Beck was honored with a University of Alberta Long Service Award. Jim has had an illustrious 35year career with the $U$ of $A$ in the area of Forest Management. He was Chair of the Department of Renewable Resources from 1996-2001. Jim continues to wear his teaching hat as a Professor Emeritus with the Department.

The Centre for Enhanced Forest Management at the University of Alberta renewed its Official Status in the autumn of 2006. The Centre provides the much-needed opportunity to integrate the multi-disciplinary components of forestry research in the development and testing of intensive and ecological management practices in the enhancement of wood production and other values. At the same time, research teams are assessing the impact of these practices on ecosystem functions and the productive capability of the forest lands. Dr. Victor Lieffers is the Director of the Centre. A critical aspect of the Centre is the discovery of new information and the training of undergraduates and graduate students in the techniques of enhanced forest management (EFM). The past decade has been reported to be the warmest in recorded history. If climate change projections for Alberta occur (increased temperature and drought in western Canada), we can expect accelerated damage to our forest from fire, drought and/or insects and disease. This change will create many research questions and opportunities for study for the researchers of the Centre of Enhanced Forest Management. There will be a need to better understand how far species can adapt to these changes. As well, we will need to know how the checks and balances on insect and disease populations will change with changed climate. This research will allow adaptation to climate change through selection and introduction of species and varieties that are adapted to environmental stresses associated with projected climate change. Work at the Centre also aims at contributing to mitigation of climate change. In some circumstances the changed climate may create opportunities to establish highyielding plantations to produce biomass for energy production as a replacement for fossil fuels.

New Faculty in the Department of Renewable Resources (members of
CEFM) include: Drs. Mel Tyree, Andreas Hamann and Uwe Hacke.

As a Chair in Tree Physiology, Dr. Tyree has established an Environmental Stress Physiology Laboratory within the Department. His research is aimed at discovering how trees deal with drought stress and avoid drought-induced transport-dysfunction. Over the course of his career, he has provided major insights into tree adaptations to drought and has been honoured with many awards, including the Marcus Wallenberg Prize, considered the forestry industry's version of the Nobel Prize. He comes to us from the U.S. Department of Agriculture Forest Service, Northeastern Research Station, in Vermont.

Dr. Andreas Hamann's research focuses on hardwood genetics, climate change, conservation and ecological genetics, as well as breeding and deployment strategies. He is interested in determining what climate conditions cause observed adaptive genetic variation, what the likely impacts of global climate change will be on resource productivity and how tree breeding and seed transfer can be adapted to mitigate potential impacts of climate change. $\mathrm{He}$ comes to us from the University of British Columbia. 
Dr. Uwe Hacke's research is in the area of plant physiological ecology, particularly related to water transport and xylem structure in woody plants. His research at the University of Alberta will focus on xylem structure and its link to water transport, stress physiology, ecology, and gene function. His research will allow for the characterizing of trade-offs which underlie drought resistance, growth rate, hydraulic and stomatal conductance and other key water use traits of boreal forest species. The results of this work will increase our ability to predict which species will be most affected by changing temperature and moisture regimes. He comes to us from the University of Utah, with a $\mathrm{PhD}$ from the University of Kiel in Germany.

Twice a year the Department of Renewable Resources hosts the Forest Industry Lecture Series, which are made possible by the support provided by partners in government and industry. Craig Neeser (B.Sc. Forestry, University of Alberta '76) was the invited speaker for our Forest Industry Lecture on March 8, 2007. Craig is President of Weyerhaeuser Canada and Senior Vice President, International Group. Craig's presentation was titled, "Where does Canada stand on Global Competition in the Forest industry?" He spoke on the importance of industry competitiveness and the need for the Canadian forest industry to be innovative and creative in finding markets for a diversity of forest products, including expertise and technology. Despite poor economic returns, uncertainties around future fibre supply, instability of U.S. markets, strong competition from regions with faster growth rates, and high cost structures, Canada does have "great fibre, a world-class workforce, certified forests coast to coast, and-the world loves wood.” In 1977, Canada's main wood products were pulp, paper, $2 \times 4$ s and plywood. Today, in addition to the traditional products, our forests are being used for energy, pharmaceuticals, chemicals, biofuels and bioproducts, and carbon sequestration. The next Forest Industry Lecture will be on November 8, 2007 and the speaker will be Dr. Robert Wagner from the University of Maine.

On March 30th, 2007 the Forest Society continued the Logger Sports tradition and showcased many of the

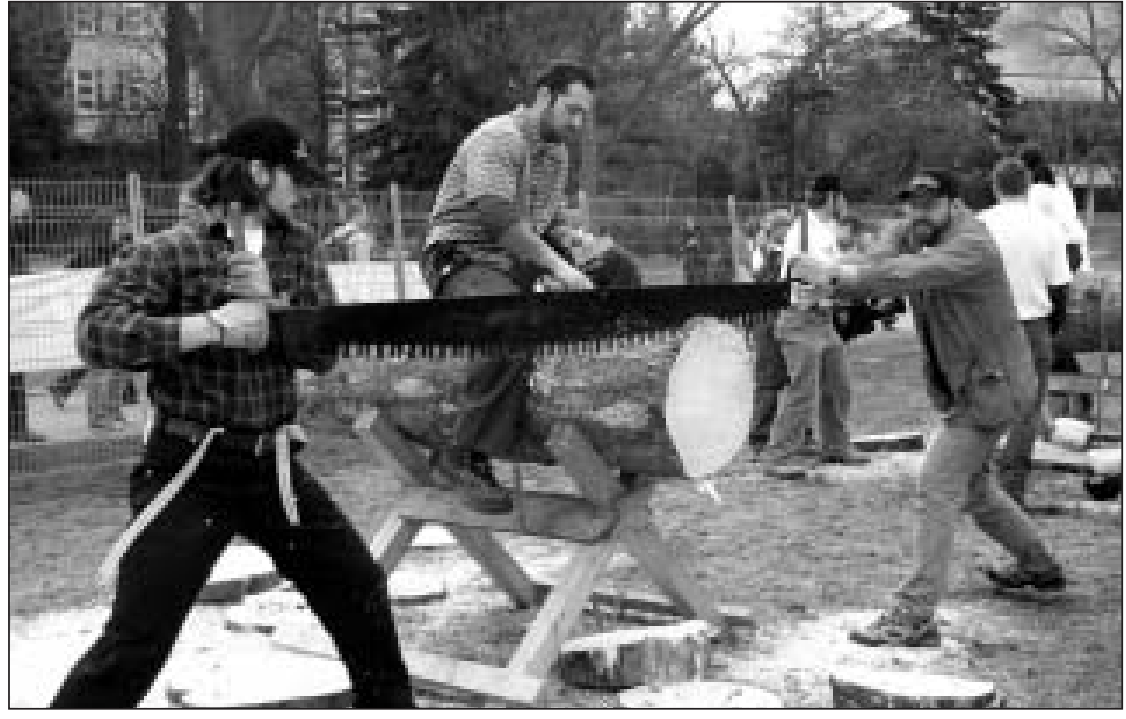

University of Alberta forestry students demonstrate Logger Sports on campus

traditional logging sport events. The Logger Sports demonstration ran in conjunction with a forestry education campaign designed to increase campus awareness of the forestry profession and its importance in Alberta. Students participated in speed chop, cross-cut, axe throw, chain toss and fire-lightwater-boil.

Eiry Spence was the 2007 Gold Medal recipient for the University of Alberta. She was selected on her demonstration of strong academics, volunteer commitment and sportsmanship. Her list of accomplishments is long, making her a well-deserving CIF gold medal winner. Academically in 2005, she received the Weyerhaeuser Community Leadership Award, the Herbert and Jeannette Hall Award in Forestry, the Forest Industry Suppliers and Logging Association Award, the CIF Rocky Mountain Section Award and the Jason Lang Award. In 2006, she received the Weyerhaeuser Community Leadership Award, the Michael Swan Memorial Scholarship and the Jason Lang Award. In 2007 she received the Jim Beck Prize in Forest Management. As an active volunteer within the community, Eiry was the Forest Society Secretary (two years), the SAF Committee organizer (two years), Chair and member of the 2006 Quiz Bowl team, member of the Logger Sports organizing committee (three years) and a volunteer for the local 4-H club. Her favorite pastime is horseback riding, and horse training (when she can find the time).

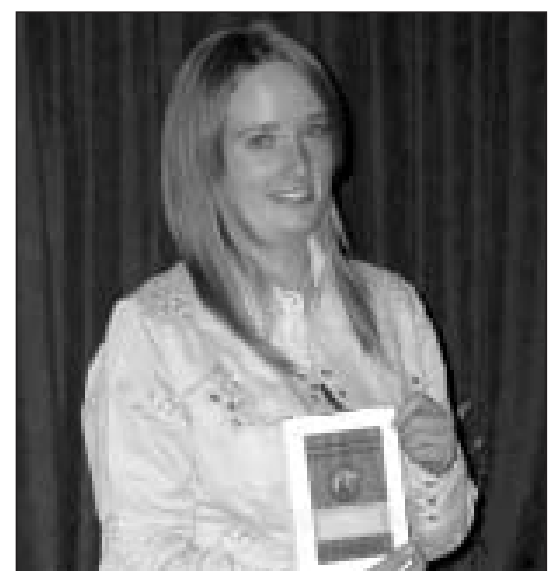

2007 CIF Gold Medalist Eiry Spence.

She enjoys many sports but has spent most of her time at $\mathrm{U}$ of $\mathrm{A}$ involved in women's ice hockey, innertube waterpolo, wall climbing, and logger sports. Following graduation, she plans to work for West Fraser: Sundre on an eight-month contract. In January 2008, she will be traveling to the South Pacific before returning to the University of Alberta to start a Masters program.

Contributions by: Sarah Gooding, Phil Comeau, Alex Drummond, Rochelle Jackson and Eiry Spence 


\section{Collège Boréal}

T/1 arc Hébert R.P.F., professor and Councillor of the Central Ontario Section of the Canadian Institute of Forestry presented Silver Rings to graduates of the Collège Boréal's Forestry Technology program. "It's widely recognized that forest technicians/technologists are key players in the forest management team. The main objective of the Silver Ring program is to recognize the academic achievement of an individual completing a Canadian forestry program."

Laurie Rancourt, Academic VicePresident, noted that she was delighted with this achievement. "The professors and myself are proud that our forestry technologists receive a Silver Ring representing their academic training. This event is the result of the exceptional work of members of our faculty."

Marc Nellis R.P.F., professor and representative of the Central Ontario Section, also took the opportunity to present the Institute's Gold Medal to Daniel Loranger for his outstanding performance in academics, sports and citizenship throughout all three years of the program. Professor Nellis noted, "Mr. Loranger highly deserves this award. He is a conscientious student who shows exceptional interest in

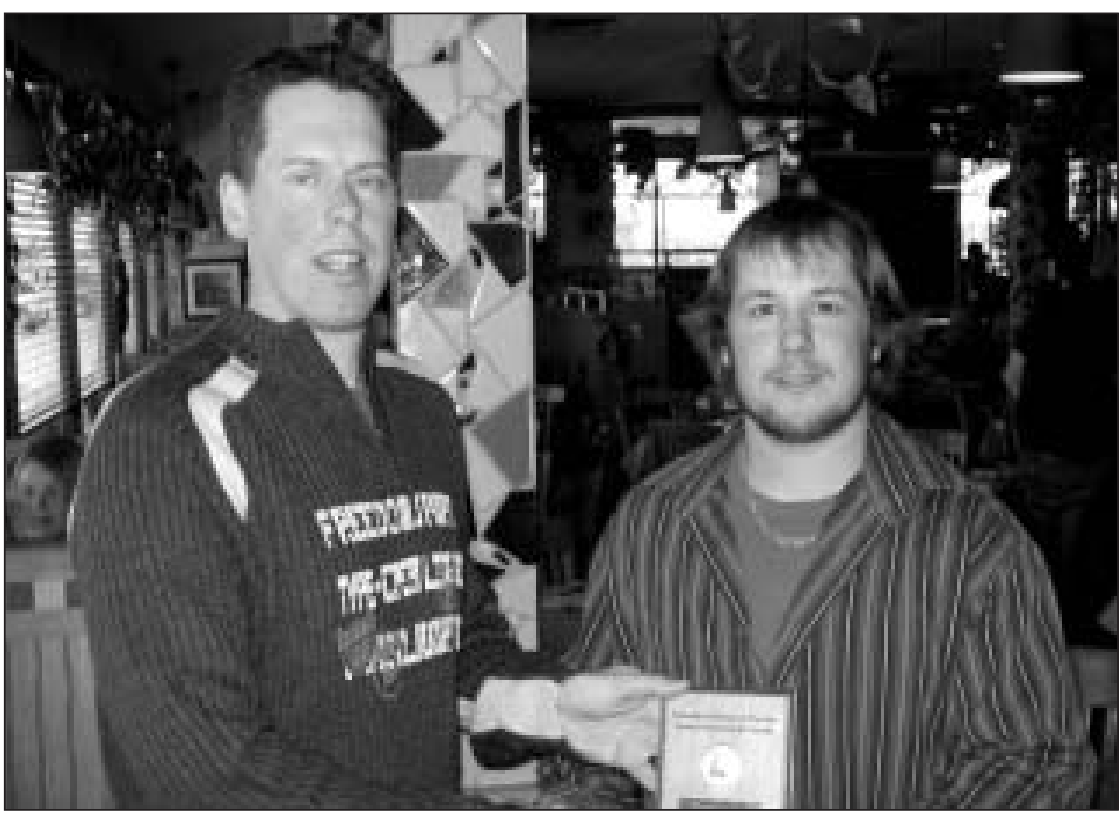

Gauche á droite : Marc Nellis, Professeur et Daniel Loranger récipiendaire de la médaille d'or et de la bourse de $\$ 100.00$ de la section centrale de l'Ontario.

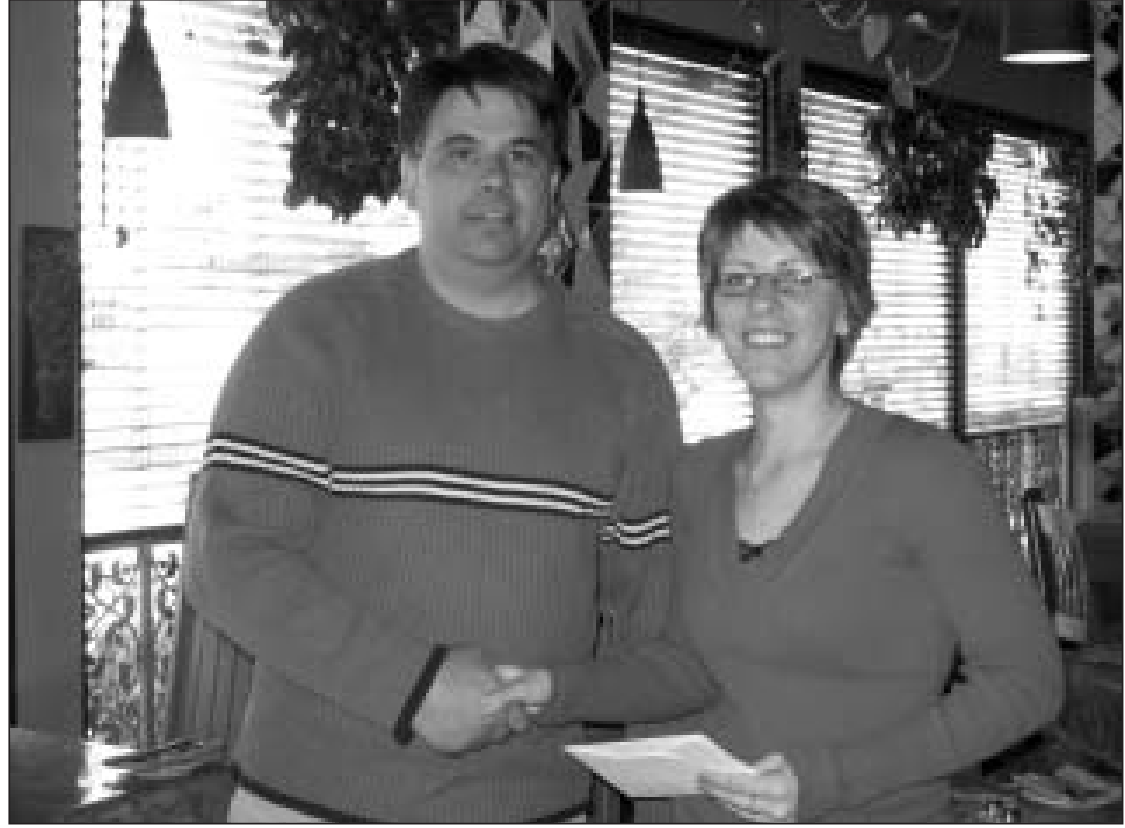

Marc Hébert and Véronique Falardeau, recipient of the Marc Hébert bursary. forestry. I had the chance to have him in my class and to appreciate his dedication and his desire to accomplished a job well." Daniel was also the recipient of the Section's $\$ 100$ bursary which goes to a third-year student who best exhibits outstanding leadership, cooperation and academic ability.

Prof. Hébert made the inaugural presentation of the Marc Hébert Award, a $\$ 200.00$ bursary given to the thirdyear student best exhibiting dedication, passion, leadership, cooperation and academic ability. The award was presented to Ms. Véronique Falardeau

Notre récipiendaire pour la médaille d'or 2007 de l'Institut forestier du Canada est Daniel Loranger. Originaire d'Earlton en Ontario, Daniel a su se démarquer de la moyenne académique du groupe tout au long des ses études en Technologie forestière au Collège Boréal et ceci en maintenant une excellente moyenne pondérée. C'est un étudiant consciencieux, enthousiaste, curieux et autonome qui manifeste un grand intérêt pour la gestion des richesses naturelles. Il n'hésite pas à appuyer ses confrères et consoeurs de classe dans leurs travaux et leurs études. Daniel a su démontrer ses qualités de leader au cours des deux derniers étés en travaillant comme technicien forestier pour Hydro-One et pour Grant Forest Products Ltd.

Durant le dernier semestre, Daniel a effectué un stage de deux mois pour la Compagnie Allmac Tree Service basé à Sudbury. Les liens qu'il a su établir, son excellent travail et sa passion pour la foresterie urbaine lui permettront sûrement de se décrocher un emploi à temps plein à la suite de son placement. Nous lui souhaitons donc beaucoup de succès dans sa carrière. 


\section{University of British Columbia}

The Class of 2007 CIF Silver Ring Ceremony was held Saturday March 17 th at the Four Seasons Hotel in downtown Vancouver. Approximately 200 students, family members, special guests, faculty and staff were present to enjoy this gala evening. In keeping with the tradition started two years ago, both UBC and British Columbia Institute of Technology students were recognized in a joint ceremony. Steve Baumber returned to the role of $\mathrm{MC}$ after a year's absence, and did his usual fabulous job of welcoming and keeping everyone on time all evening long. His wit and charm are legendary! The keynote speaker was the Hon. Rich Coleman, Minister of Forests and Range, who gave an encouraging and inspirational speech about the many opportunities and challenges awaiting the new graduates. He also offered to assist UBC, BCIT and other provincial educational institutions with our recruitment efforts_-and we will be vigorously pursuing this opportunity.

Karen Burnett and Ahmed Omran spoke about the highlights of their time in UBC Forestry from the perspective of the Forestry Undergraduate Society (FUS) Co-Presidents. David Gibson, BCIT class representative, talked about his BCIT forestry program and future aspirations.

Alex Forrester, graduating student and this year's CIF student representative on the FUS also addressed the gathering with a wonderful and humorous speech. Alex's father, Cam Forrester (UBC Alumnus), was in the audience to enjoy the spectacle of seeing his son make this presentation. Alex spoke about his experiences with UBC Forestry, and also encouraged students and others to get more involved with the CIF.

Doug Stables, CIF national President (and UBC Forestry alumnus) spoke about the Canadian Institute of Forestry and the history of the Silver Rings. The CIF gold medal for the most outstanding Forestry student was presented to Jordan Winch from BCIT and to Stephanie Ewen, BSF Forest Resources Management student from UBC. Daniel Splawski received the Charles Larre medal for the most outstanding Wood Products Processing student. Daniel was unable to attend as he was backpacking in Guatemala.

The evening concluded with the ring ceremony-the traditional presentation of CIF Silver Rings to signify completion of an accredited Canadian forestry degree or diploma program. Dean Saddler was unavoidably absent this year. However, Peter Marshall, Associate Dean Undergraduate Students, aply filled in and read out the names of the UBC graduating students-with humourous "blurbs" for all. Norm Shaw had the same honour for the BCIT students. Doug Stables presented the Rings to all students and was assisted by Professor Gordon Weetman (CIF Vancouver Section Chair).

Special guests for the evening included Mike Apsey, Gerry Burch and Stirling Angus (UBC alumni), and Dwight and Diane Yochim of the ABCFP. All award winners and speakers were given an autographed copy of Gerry's new book "Still Counting the Rings."

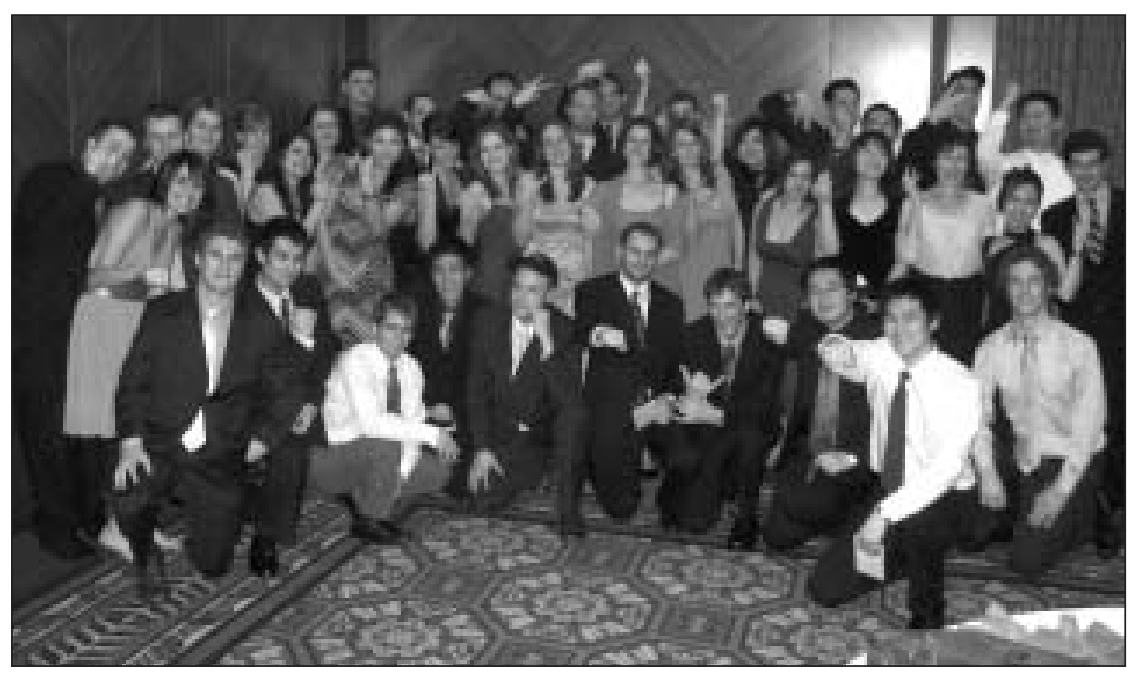

UBC Students showing off their Silver Rings.

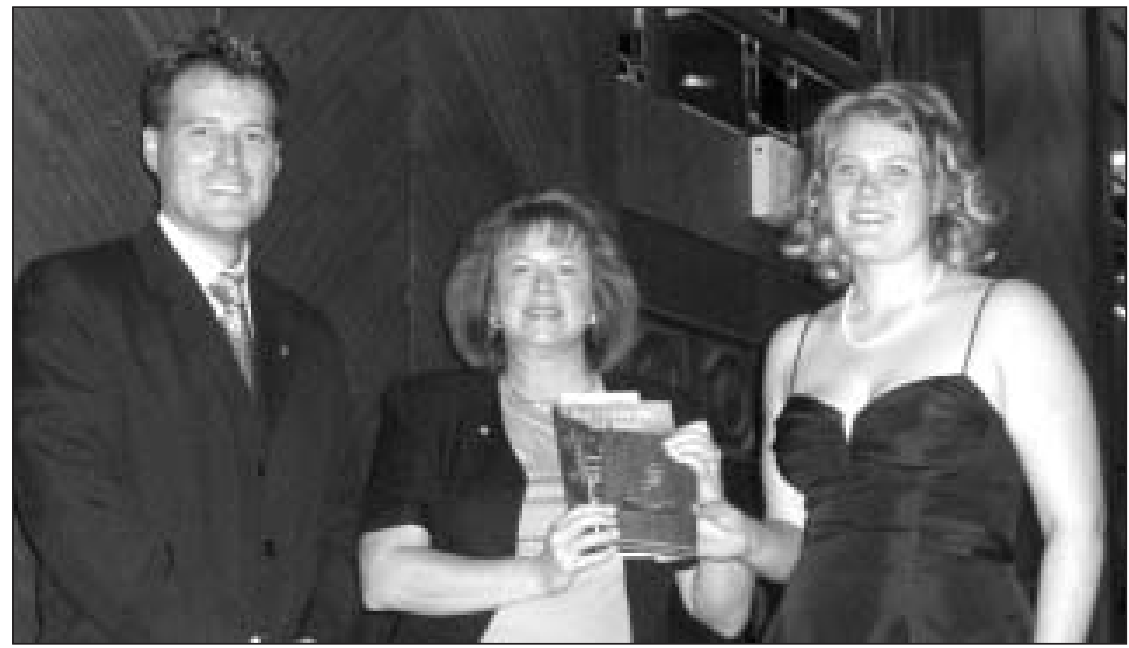

Doug Stables, left, CIF/IFC President, Candace Parsons, and Stephanie Ewen. Candace holds Stephanie's Gold Medal plaque plus a copy of Gerry Burch's Still Counting the Rings presented to all speakers and award winners. 


\section{CIF Gold Medal Presentation}

In 1953, UBC was the first and only school to have a Gold Medal recipient. Over the next 20 years, three more universities joined this program and finally all seven universities offering a forestry program are participating. Since 1992, the CIF Gold Medal has also been awarded to students graduating from each of the 21 forestry technical schools. So who gets these gold medals, you may ask? The recipient is selected in recognition of outstanding scholarship, sportsmanship and citizenship-based on their performance throughout ALL the years of their program, not just the final year. So, basically, we search for the most outstanding, well-rounded student out of each year's class.

This year's Gold Medal winner from the UBC Faculty of Forestry is Stephanie Ewen. Stephanie started out in the Faculty of Science at UBC before seeing the light and switching to the Faculty of Forestry. In fact, she responded to an invitation by our recruiting staff to come to the Malcolm Knapp Research Forest for a tour and a free BBQ dinner. We're still not sure if it was the program or the excellent BBQ steak that won her over in the end (she told us afterwards that it was definitely the steak dinner!).

Stephanie has excelled academically every year, always on the Dean's Honour Roll and receiving many scholarships. However, I am told that she is also the first person to offer assistance to fellow students with their labs or other coursework. Her Faculty advisor says that Stephanie is intelligent, dedicated and hardworking, but it is her confidence and determination, combined with a wonderful personality, that make her such a natural leader.

She has been active in student affairs, and was this year's Forest Resources Management and Alma Mater Society representative on the Forestry Undergrad Society. She regularly helps to organize and manage student events, and also plays soccer on a local team. A fellow student tells me that Stephanie saved his bacon during last year's alumni tour at the Malcolm Knapp Research Forest. The two were tasked with explaining their FRST 424 (fourth year capstone course) field project and answering tough questions from alumni-people like Tony Kozak and Gerry Burch-who were grilling them

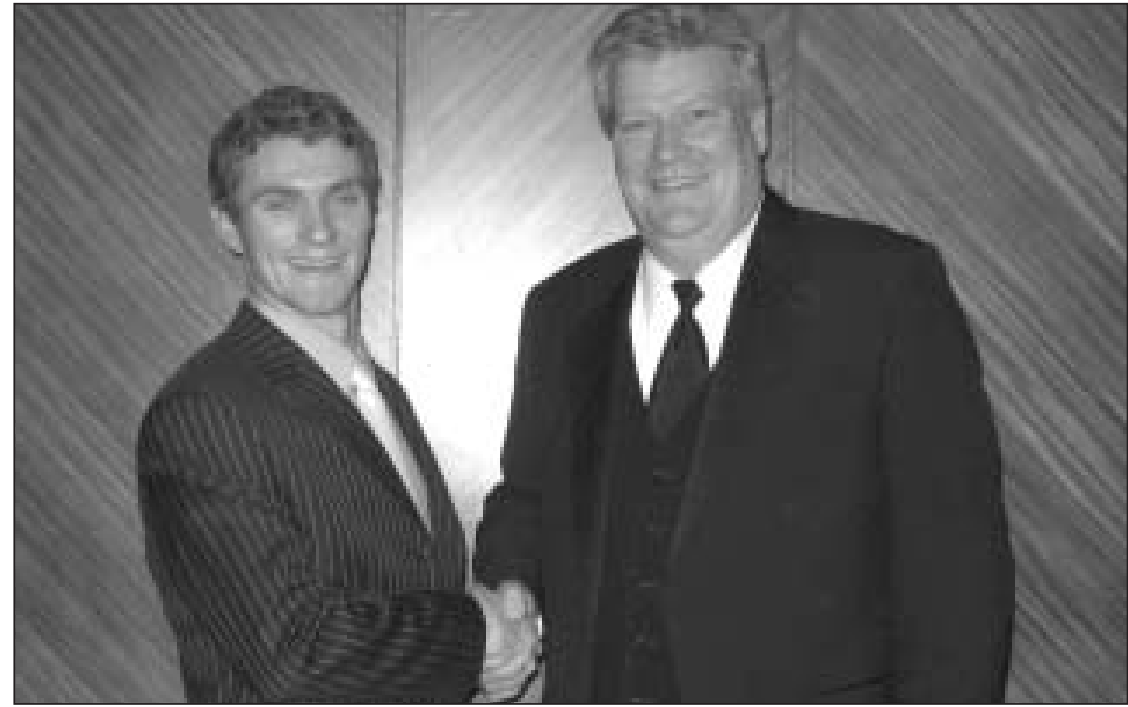

Alex Forrester, left, with Minister Coleman. Alex was this year's CIF/IFC student representative on the Forestry Undergraduate Society, and along with Candace Parsons, helped to organize the Silver Ring ceremony.

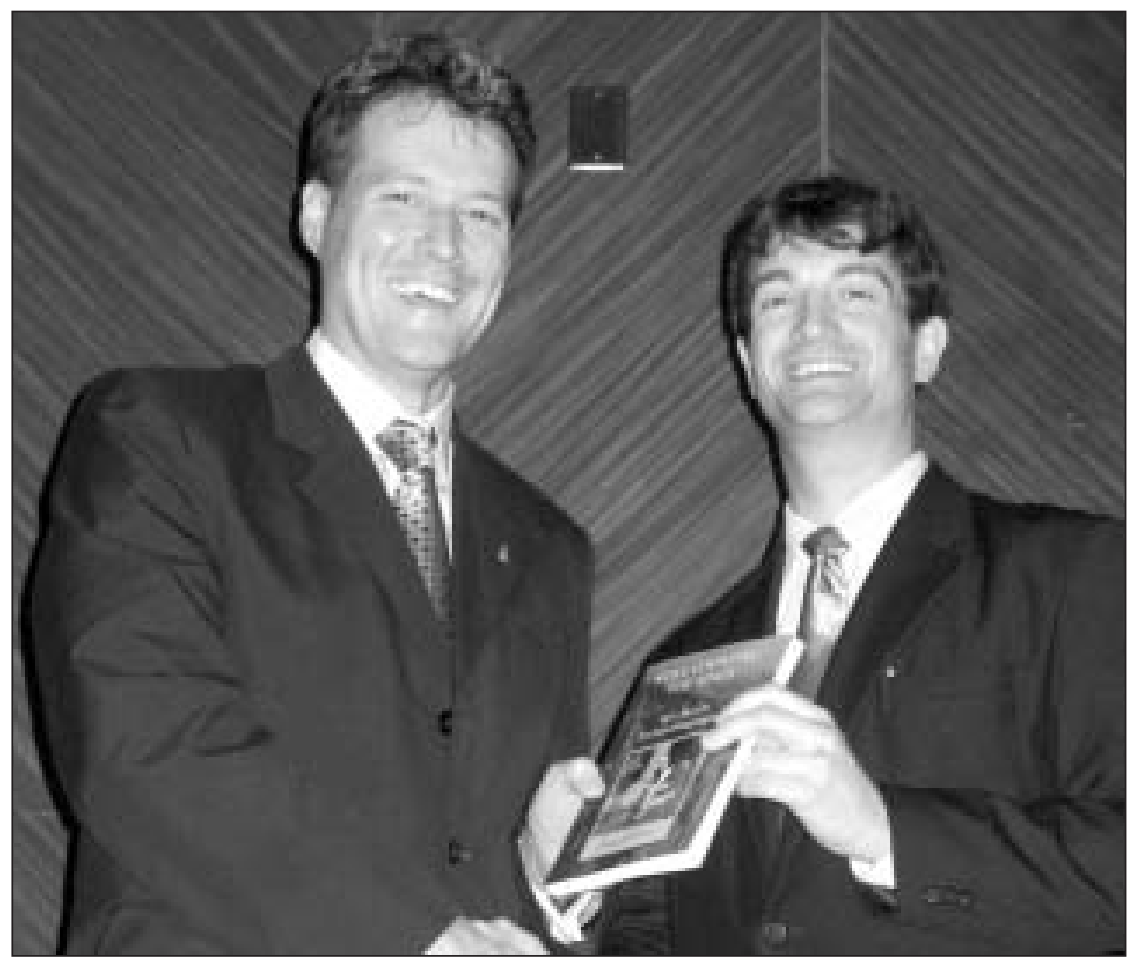

Doug Stables, left with Steve Baumber, Forestry Masters student, former UBC Forestry Recruitment Officer, and Silver Ring ceremony Emcee.

with great intensity. Luckily, Stephanie saved the day with her quick thinking and clever responses. Even Gerry was impressed, I'm told, which almost never happens, as many of us know!

In addition to handling difficult coursework, Stephanie is also a rafting guide on the Chilliwack River, well respected for her excellent rafting skills.
Congratulations, Stephanie, on all of your accomplishments, including being selected as this year's CIF Gold Medal recipient for the UBC Faculty of Forestry!

Submitted by:

Candace Parsons RPF

Director of Student Services UBC Faculty of Forestry 


\section{Université de Moncton (Campus d'Edmundston)}

M édaille d'or de l'IFC 2007

Cette année, la finissante de la Faculté de foresterie de l'Université de Moncton, Campus d'Edmundston (UMCE), Marilène Beaulieu, s'est méritée la Médaille d'or de l'IFC. Originaire de Saint-Basile, au NouveauBrunswick, Marilène s'est distinguée tout au long de ses études universitaires par son rendement académique supérieur, ainsi que par son engagement et son implication dans l'Université et la communauté environnante.

Elle a été conseillère sur le Conseil étudiant de la Faculté de foresterie, représentante étudiante à l'Association des Anciens et Anciennes de la Faculté de foresterie, et membre du Comité organisateur de la $21^{\mathrm{e}}$ édition de la conférence CONFOR, pour étudiantes et étudiants de cycles supérieures en foresterie et sciences de l'environnement de l'est du Canada et des ÉtatsUnis tenue à l'UMCE en février 2007. Sur le côté sportif, Marilène est membre de l'équipe d'Ultimate Frisbee de l'UMCE depuis 2003. Au fil des ans, elle s'est vue attribuer plusieurs bourses de mérite académique et para-académique.

Marilène a aussi été très active dans la communauté, soit en tant que bénévole pour les Oeuvres de l'Hôtel-Dieu de Saint-Basile, au souper bénéfice de Canards illimités, et membre du Conseil d'administration du Club d'Ornithologie du Madawaska.

\section{Lakehead University}

It the end of March, Natural Resources Minister David Ramsay announced that Lakehead University will receive \$140 000 annually until 2010 to enhance its ability to provide technical support to the value-added wood products industry. These funds will work in conjunction with Forintek and a grant to Confederation College, where a specialized training program will be developed. The university can now seek two new research chairs and an enhancement of its wood science facilities. The innovation and training will come only after significant stakeholder consultation, and will support

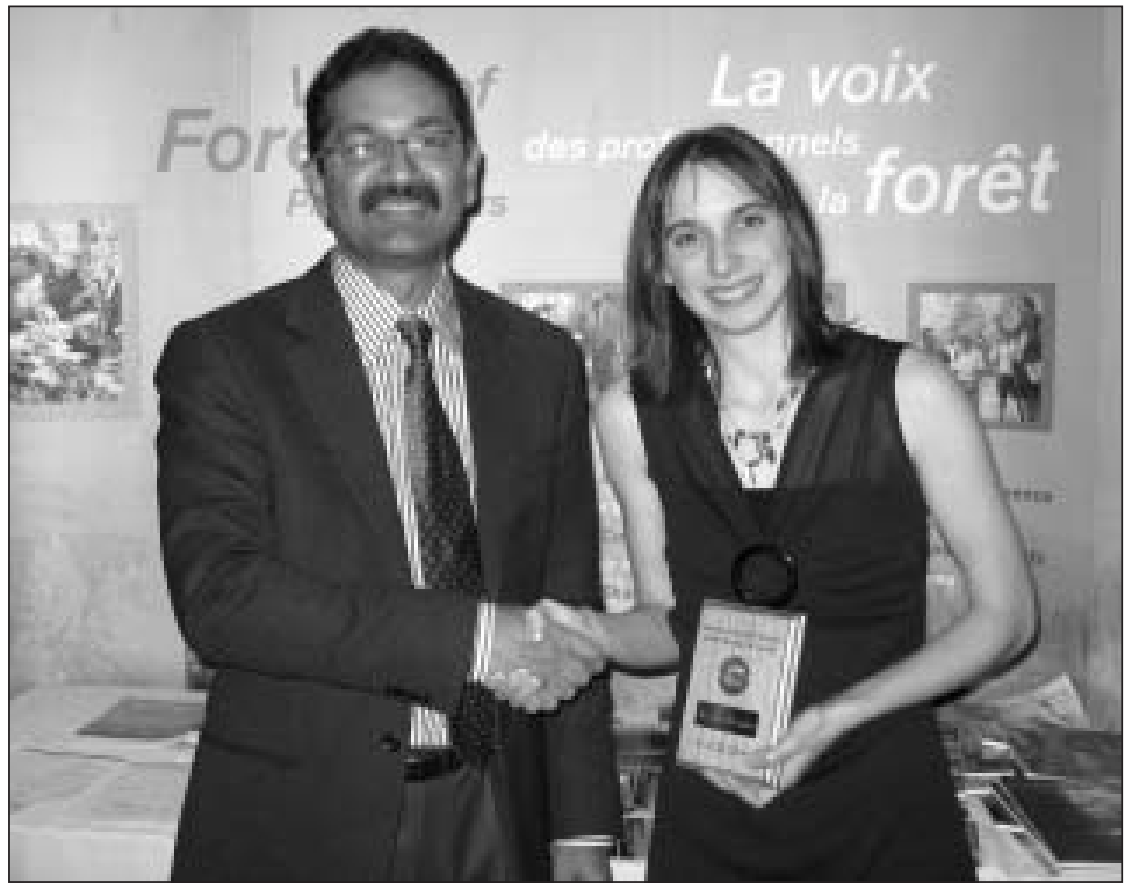

Fred Pinto (Premier Vice-président de l'IFC) présente la médaille d'or à Marilène Beaulieu à la Conférence Sylvicon tenue à Fredericton le 15 février 2007.

Étudiante inscrite dans le régime régulier du programme B.Sc.F., elle en a profité pour réaliser des emplois d'été comme auxiliaire de recherche à la Faculté de foresterie sur des projets réalisés à notre Forêt expérimentale à Sainte-Anne-de-Madawaska, et à l'Érablière de la Montagne Verte. Elle a aussi occupé des postes au ministère des

Ressources naturelles du NouveauBrunswick, Section sylviculture, et au Jardin Botanique du N.-B.

Marilène a un intérêt marqué pour les oiseaux forestiers et, dès l'automne 2007, a l'intention de poursuivre ses études au niveau de la maîtrise dans le domaine de l'aménagement faunique.

\section{Lakehead}

UNIVERSITY

Aboriginal and other value-added wood product manufacturing opportunities in Northwestern Ontario. Initially, however, Minister Ramsay put forward ideas such as: car assembly from 50\% bio-construction; using wood products in the pharmaceutical industry; and developing bio-fuels. Ramsay's program is one of several measures the Government has in place to help make Ontario's forest sector more competitive. Dean Reino Pulkki called the announcement an important event that culminates nearly one year of planning to enhance the wood science facilities. Vice President of Research, Dr
Rui Wang intends to use the momentum from this new grant to apply for capital funding from the Canada Foundation for Innovation and plans a complete new research facility on the university campus.

Also in March, students in the Forestry and in the Environmental Studies/Forest Conservation programs received their Silver Rings from John Pineau, representing the CIF. Lakehead is unique in that it is the only university for which the CIF/IFC recognizes the Conservation program as one of the "welcome" programs into the profession. As tradition has dictated, the event 
substitutes for the formal convocation when students receive their degrees as the time when family members travel long distances to celebrate the students' entry into a professional career.

The ceremony is an event fully organized by the students and held at Old Fort William, a scenic historic site. The temperature on the evening was warm and the sense of anticipation regarding special awards was considerable. There was also conspicuous warmth in the fresh exchanges between faculty members and parents who each shared an investment-albeit a different kind-in the mentorship of the young people being honoured. Faculty member Peggy Smith served as master of ceremonies and Dr John Naysmith did the roll call for the students. Several local sponsors contributed to the success of the event. One of the most memorable parts of the evening was the valedictorian address by Aaron $\mathrm{T}$. Palmer, a graduate of the HBSc. program in Forestry. We have decided to publish Aaron's speech in its entirety below.

\section{Valedictorian Address, Silver Ring Ceremony}

"Welcome Faculty, staff members, representatives from the Canadian Institute of Forestry and Ontario Professional Foresters Association, fellow students, family and friends. I am grateful that everyone was able to attend tonight's special ceremony. By your presence, we have not only recognized our class's achievement, but also further authenticated the significance of this event.

Before I begin, I would like to specifically thank several groups of people, without whom this event would not be possible: the Faculty and staff who have invested countless hours providing us with the guidance needed to reach this stage and groundwork of knowledge we will use in our future endeavours; the CIF, for it's generosity in supplying the Silver Rings - the rings represent a congenial welcome into the profession, and we accept these gifts with gratitude. I would like to especially acknowledge the parents of the graduating class: thank you for the unwavering support and encouragement you have shown us throughout the past four years. The foundation you have provided is reflected in our success, and without this support we would not be here this evening. And finally, many thanks to the

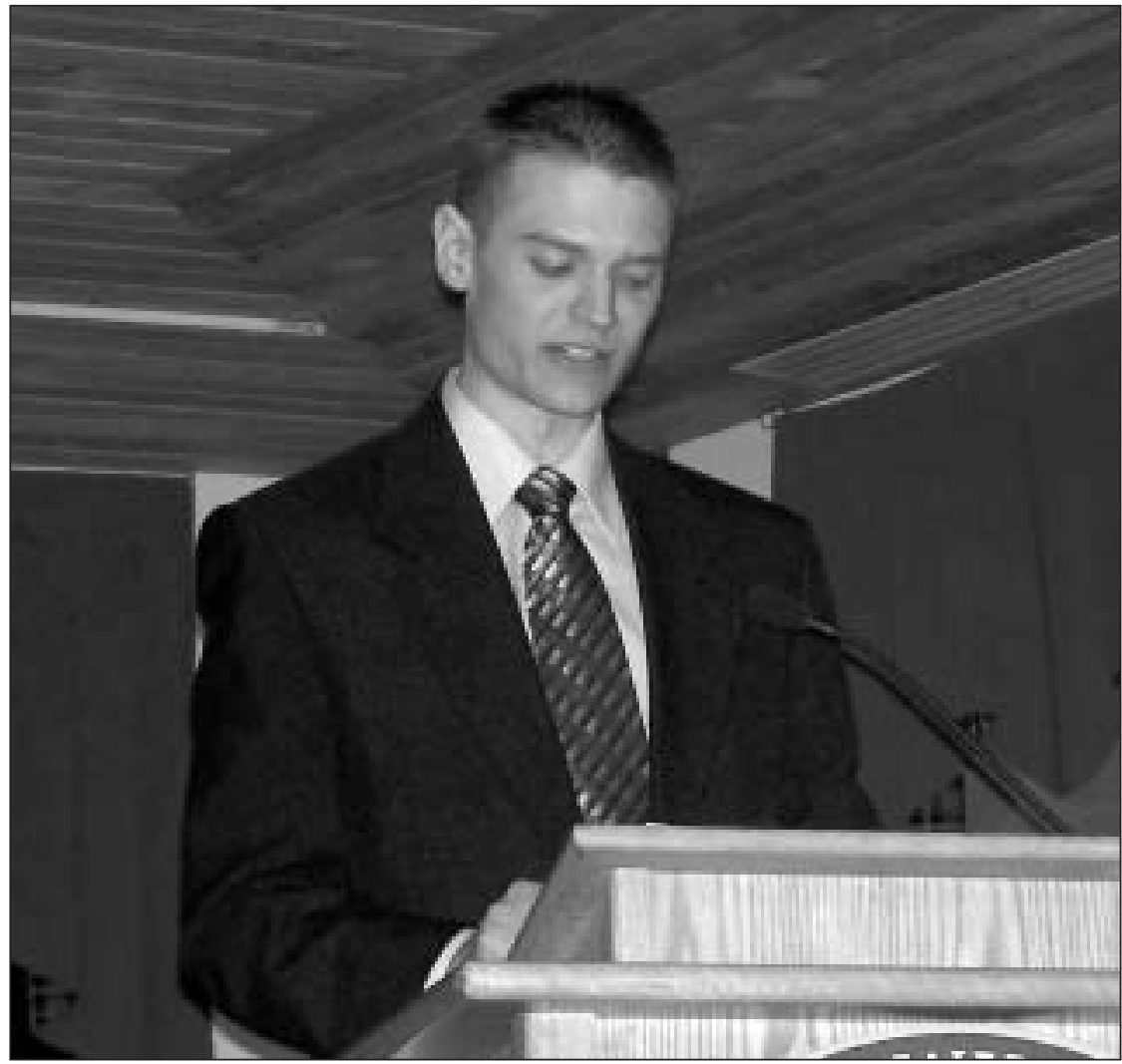

Aaron Palmer

ring ceremony committee for making this special evening a reality. The effort you have put into this event does not go unnoticed, and we thank you. I must say how honoured I am that my peers have selected me to represent our class; this is something I truly value. Thank you for this opportunity.

As we are here to celebrate our entrance into professional forestry, I thought it fitting to describe our academic journey using the analogy of a forest stand. Much like us, a tree community undergoes considerable changes as it grows over time, and these are categorized into four distinct stages: stand initiation, stem exclusion, understory reinitiation and old growth (Oliver and Larson 1996). I feel that our experiences during the past four years can also be represented by these stages, and I will use this analogy to share the story of our journey.

\section{Stand Initiation}

In first year, our class underwent stand initiation as we were thrust into a new world, much like seeds landing on a barren landscape. The first day of field school involved getting onto a bus with a group of people we didn't know, with feelings equally divided among excitement, anxiety and uncertainty about what would take place over the next few days. And like seeds from different trees, our class included people from many different backgrounds: some from large cities, others from rural locations; collectively we represented several provinces. This diversity would make our cohort rich with perspectives, although they were all underpinned with a common desire to learn about the forest and to become stewards of this important natural resource.

As we moved through our first semester, the workload was like a hardened soil. Trying to get established proved more challenging than expected. The endless memorization of dendrology, learning statistics in what seemed to be another language and both lab and lecture final exams in mensuration proved to be academic adversities not easily overcome. However, with determination, we were able to penetrate the hardened soil by passing these courses; thus, we began establishing our own root systems. It is with these roots that we anchored ourselves in the soil of knowledge that will continue to nourish us for the rest of our lives. 


\section{Stem Exclusion}

With the completion of first year, we entered the second stage of development, the stem exclusion stage. During this phase, the number of trees within the stand begins to decrease, and the overall density of the community starts to decline. Similarly, our class size diminished, as several of our original members decided to pursue interests outside of forestry. As our group became smaller, the interrelationships within our community grew proportionately stronger. We recognized that success in the program would require us to support one another, much like the mutualistic relationships exhibited between forest trees.

Without these strong relationships and encouragement, we probably wouldn't have got through the times that tested our resolve. Tests came in the form of the experimental design project, which had many of us working overnight in the computer labs, and our genetics labs, which I am certain have taken no less than three years off my life. Nonetheless, we collectively endured these challenges, and like trees overcoming inhibitive vegetation, grew into our third stage of development: understory reinitiation.

\section{Understory Reinitiation}

This stage is marked by the introduction of a new group of trees, which enter into the community, adding desirable complexity and diversity into the forest. Similarly, we welcomed an infusion of graduates from college forestry programs into our class. Our new peers exhibited both technical skills and pragmatic knowledge, while bringing forth great enthusiasm for the practice of forestry. These students are equally responsible for creating the great character that defines our graduating class.

Although both sections endured similar academic challenges, our newest members were faced with an even greater workload upon entering the program. I can't fathom the stress involved in completing one insect and two fungi collections, advanced forest genetics, pathology and advanced mensuration all in one semester. However, just as many pioneer species will provide nutrients and shade for those developing in the understory, many original students offered their support to the newly established cohort. Such cooperative efforts came from the mutual goal of accomplishing our degree in unison, and the desire to coexist in a steady state before embarking on our next adventure.

Even though we had the ambition to grow and succeed, these factors were not solely responsible for our reaching the latter stages of development. Just as no tree can reach great heights without soil, water and nutrients, our vigour was also dependent on the essentials of knowledge, guidance and inspiration brought forth by the Faculty and staff. And much like the greatest timber yield comes from trees grown on the best quality sites, our teachers provided us a "site" so rich in these essentials, that our own potential was exponentially increased.

\section{Old-Growth Stage}

After committing several years to studying and expanding our base of knowledge, we entered the old-growth stage of our development. This period is perceived by many to be the state in which a forest exhibits its most valuable traits. Longevity, species richness, and strong interrelationships are commonly associated with old-growth forests. Such attributes could fittingly be applied to our class, especially as we moved through the final episodes of our academic succession.

Our class, though comprised of individuals who entered the program at different times, began to form one unified cohort as we entered the last stages in our journey. Our fourth-year field school allowed us to truly get acquainted with one another, and became a pivotal moment in our amalgamation. In our two weeks together touring the forests of central Ontario, the arbitrary boundaries of our past backgrounds were dissolved, and we bonded together to form one cohesive and well-integrated class.

Even with this integration, we would retain our diversity through the different perspectives and strengths contributed by each person. With our unique portfolio of individuals, our relationships helped us to work collectively towards our degree, and also stretched far outside the classroom. Events such as the "plaid" party, hockey tournament, ice-fishing derby, and especially the "Miss Forestry" pageant will remain memorable portrayals of how well our group functioned together regardless of the situation.

\section{Conclusion}

Following the old-growth stage in the boreal forest, one might expect a fire disturbance to signify the end of a forest's lifecycle. However, this event only represents a natural transition into a new, rejuvenated stand, much like the vital transition between our academic journey and the endeavours that await us ahead.

Our metamorphosis from student to professional is worthy of celebration, but we should also remember that each new privilege is certain to be followed by a great amount of responsibility. The field of study we have followed is unique in that the decisions we make today will greatly affect many people for generations to come. It is for this reason that we must earn the highest levels of competence, while recognizing the long-term consequences of our actions every day of our professional lives.

Although challenges have always been inherent in the field of forestry, our class is graduating in a time of unprecedented difficulty for our discipline. We are constantly reminded of mill closures and the struggles facing the industry, the threat of climate change, and the desperate need to bridge the gap of communication between ourselves and the public whose interests we serve.

But I think these big challenges present even bigger opportunities, and I feel we are all well prepared to become innovators of viable solutions that will change our practice for the better. This great ability stems from the life-changing experiences we have undergone during the past four years. These came not only through intellectual development, but also in the form of friendships that will remain with us for the rest of our lives. Above all, I am confident each of us will use what we've learned to think critically and act in good faith when making decisions about the forests we all depend on. Through such honourable efforts, we can benefit our communities, our societies and our planet now and into the future, and in doing so we can truly become stewards of the forest."

\section{Aaron Palmer}

\section{Literature Cited}

Oliver, C.D. and B.C. Larson. 1996. Forest stand dynamics. Wiley, New York. 520 p. 


\section{Cégep de Rimouski}

M

on passage en technologie forestière au Cégep de Rimouski n'est pas un hasard. Depuis mes plus lointains souvenirs, la forêt a toujours été présente dans mon quotidien. Fils de travailleur et producteur forestier, ainsi que producteur acéricole, mon père a su me transmettre sa passion pour la forêt. Mon expérience de travail à œuvrer comme ouvrier sylvicole avec mon père m'a permis d'acquérir de bonnes connaissances dans ce domaine et cela m'a beaucoup aidé lors de ma formation.

Mes trois années d'apprentissage ainsi que mes stages en alternance travailétude ont confirmé la passion qui ne cesse de grandir et que j'éprouve envers le domaine forestier. De plus, la nature me permet de pratiquer mes loisirs préférés qui sont la chasse et la pêche.

C'est pour ces raisons que je poursuivrai mes études au niveau universitaire, à l'Université de Moncton, en sciences forestières dans le but de contribuer à la conservation de la plus grande ressource qu'est la forêt.

David Beaulieu Finissant en Technologie forestière

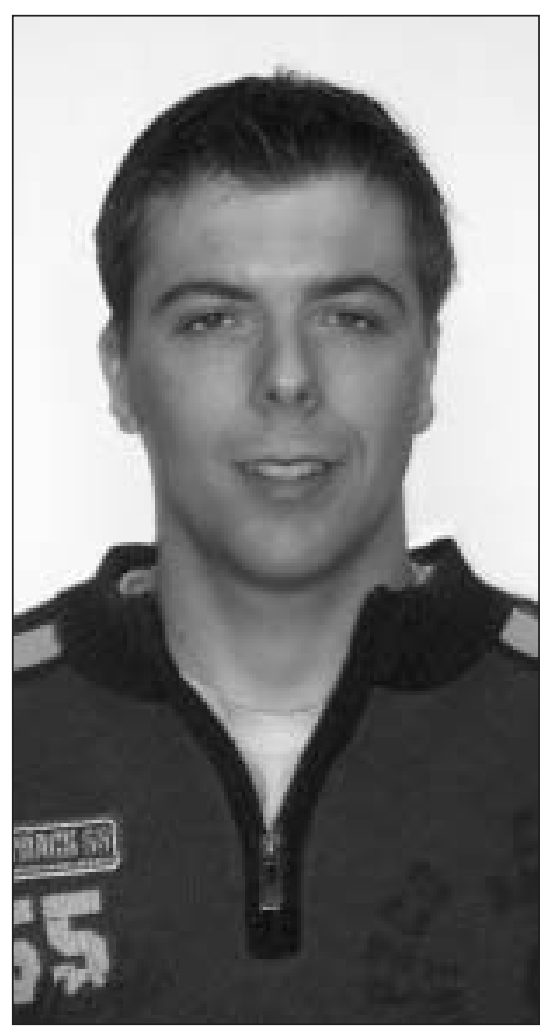

David Beaulieu, récipiendaire pour la médaille d'or 2007.

\section{Université Laval}

Le 7 avril dernier avait lieu à Québec - la cérémonie de la remise des joncs de l'Institut forestier du Canada pour les finissants en génie forestier de l'Université Laval. Cette année, la médaille d'or a été décernée à Mme Sandra Veillette, étudiante finissante du programme en aménagement et environnement forestiers. Cette jeune dame de l'Abitibi s'est distinguée par son implication dans le milieu étudiant tout en maintenant une excellente performance académique. Mme Veillette s'est notamment impliquée dans le comité d'initiation, au Forum des jeunes du $12^{\mathrm{e}}$ Congrès forestier mondial, dans l'organisation du Salon de la forêt, dans l'association étudiante, dans le comité de programmes et dans le comité des finissants. Avec toutes ces expériences et un tel dynamisme dans l'implication, Mme Veillette est vouée à une carrière prometteuse dans le milieu forestier.

\section{University of Toronto}

\section{Caculty of Forestry Celebrates 100 Years}

The Faculty of Forestry at the University of Toronto was founded on March 28, 1907, as the first post-secondary forestry program in Canada. The first Dean was Dr. Bernhard Fernow, who arrived in Toronto from Germany, via the United States.

To mark this momentous occasion, the Faculty has planned many celebratory events, which will be held throughout this year (please see advertisement elsewhere in this issue).

The first event took place on the actual anniversary of the founding of the Faculty. Therefore, on March 28, 2007 a Centennial Launch was held at the University's Faculty Club. Over 100 people attended from a wide array of backgrounds. Invitees included: current academic, administrative and technical staff; emeritus professors; current students; key Faculty Alumni; senior University Administrators; Deans and

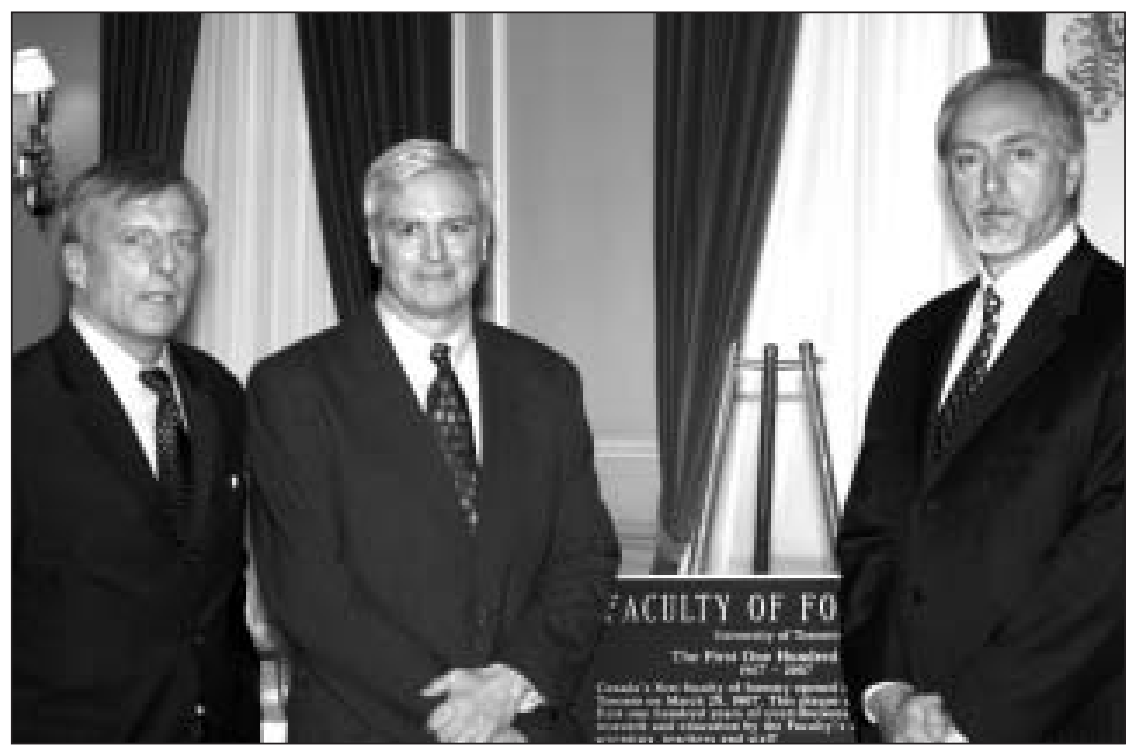

[left-right] The Honourable David Ramsay, Ontario Ministry of Natural Resources, Dean Tat Smith and Roger St. Louis, Ontario Forestry Association President, in front of the new plaque. 
Principals from fellow Faculties and Schools; major donors; key contacts in industry and government; and centennial committee volunteers.

After some opening remarks by Dean Tattersall Smith to set the stage, Dr. David Naylor, President of the University, spoke about the role of the Faculty within the University and the Faculty's historical significance. Mr. Steven Anderson, President of the Forest History Society, gave a biographical presentation about the life and times of Dean Fernow. Dr. Kandyd Szuba (BScF, 1977), a biologist with Domtar, spoke on behalf of the nearly 3000 graduates from the Faculty. The Honourable David Ramsay, Ontario Minister of Natural Resources, brought greetings from the Ontario Government and spoke about the various linkages between his Ministry and the Faculty. Dean Smith then read a Letter of Greeting from the Mayor of Toronto, David Miller. Unfortunately the Mayor was unable to attend in person.

The final speaker of the evening was Roger St. Louis, President of the Ontario Forestry Association. The Association presented a plaque to the Faculty to honour this occasion. The plaque will be placed on a boulder near the entranceway to the Faculty and reads:

"Canada's first faculty of

forestry opened at the University

of Toronto on March 28, 1907.

This plaque commemorates the

first one hundred years of contri-

butions made to forestry science

and education by the Faculty's

students, alumni, scientists, teach-

ers and staff."

In closing, Dean Smith led all present in a "toast" to the first 100 years. For further information about upcoming centennial events and how you can participate, please visit our Faculty Web site at: www.forestry.utoronto.ca and click on the Centennial banner.

\section{Lecture Series: An Evening with Margaret Atwood}

The Lecture Series is one of the featured components of the Faculty's centennial celebrations. The first Lecture was held on April $5^{\text {th }}$ at the Isabel Bader Theatre, featuring Margaret Atwood, Canadian author and environmentalist. This event was sold out quickly and attended by over 500 people from various walks of life, including a major contingent from the University's Presidents Circle.

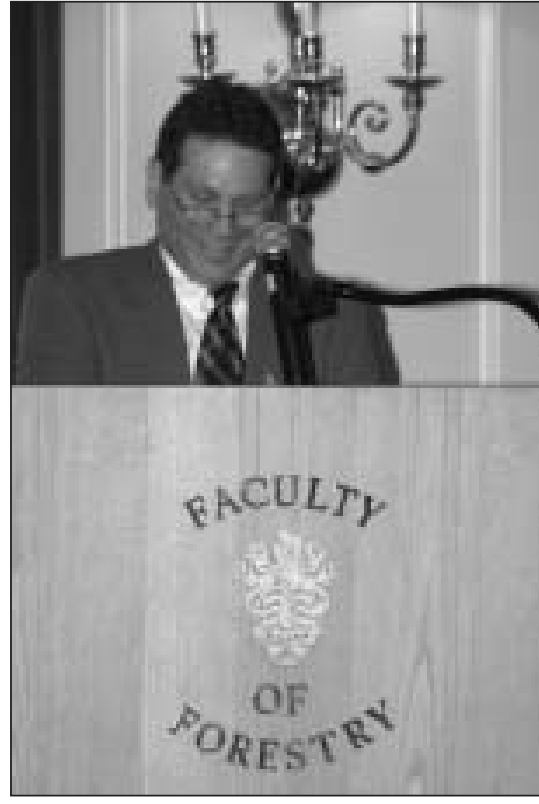

University of Toronto President, Dr. David Naylor.

Ms Atwood spoke on the topic: Canada's Forests: Exploring our Connection.

The Pre-Lecture Reception was held in the Alumni Hall at Victoria College, with drinks and a buffet spread of finger foods and desserts. The energy and excitement of the crowd rose as they made their way across the courtyard to event.

After some opening remarks by Dean Tattersall Smith to set the stage, Ms Atwood spoke about the role of forestry in our lives today. Her lecture consisted of three main components: 1) her background and relationship to the Isabel Bader Theatre for the main forestry; 2) the mythological symbology of trees in literature; and 3) the present situation of forest conservation.

She began with discussing her father, Carl Atwood, an entomologist, her greatest inspiration and exposure to forestry. She then presented photos from her childhood growing up in the forests of northern Québec. Her clever wit and infectious humour had the crowd laughing within minutes.

She then wove her words to discuss the legends and myths that trees have represented in literature throughout history. She described the forests' role in famines and plagues, their relationships a variety of literary vignettes, she described several key quintessential She ended this component by quoting an Indian proverb, "Forests precede civilization; deserts follow it."

The last portion of her lecture focused on forests in the present day and society's attitudes towards them. She stated that "the value of early education is increasingly recognized" and that outdoor classrooms should become more prominent in Canada. She also discussed humanity's innate "fear of the forest" as the key reason for global abandon. Her evocative language took the crowd through an emotional journey of compassion.

In closing, Hilary Thorpe, a Forestry Ph.D. candidate, with her warm and dynamic presence, thanked Ms. Atwood for her insightful speech. With a wave of delight, the crowd left the theatre and the memorable evening drew to a close. to gods and goddesses and finally using examples of forests as mythic symbols.

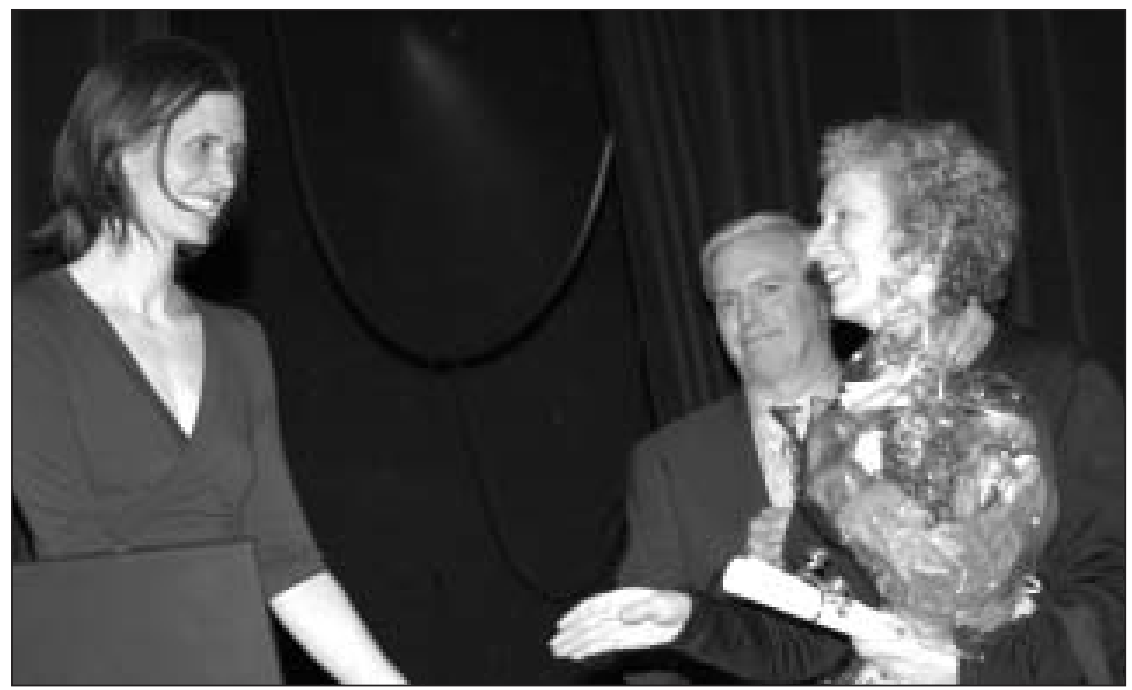

Hilary Thorpe (left) thanks author and environmentalist Margaret Atwood, with Dean Tat Smith in the background. 


\section{Confederation College}

\section{c irst CIF Silver Ring ceremony}

The CIF Silver Ring is a symbol of professional responsibility, to be worn with pride. That's what graduates of the Confederation College Forestry Technician program were told as they received Silver Forestry Technician Rings from the Canadian Institute of Forestry at a special ceremony April 10. This was the first forestry ring ceremony for the College's Forestry Technician program, which received national accreditation this year.

All graduates of the College's forestry program going back to 2004 are eligible to wear the ring as a welcome to the profession of forestry and a reminder of their responsibility to manage the forest for future generations. The rings are a symbol of achievement marking the completion of a recognized forestry program and represent a national bond amongst Canadian forestry graduates.

"We celebrate the achievement of our forestry graduates," said Kim Fed- derson, Vice President Academic of Confederation College. "The quality of the Confederation College Forest Technician program prepares them to enter the profession of forestry with the right skills and knowledge. A key strength of the program is the $100 \%$ student placement in forestry co-op programs during which time their education is enhanced by practical work in the field," said Fedderson. "I was extremely proud to attend this ceremony to personally congratulate each new forest technician on behalf of Confederation College."

"The CIF recognizes the value of the education provided to Confederation College forestry technicians and bases its accreditation on high-quality instruction and successful co-op placements," said John Pineau, CIF Executive Director. "The forest industry requires people who will be vigilant managers of the forest throughout their careers. We are pleased to welcome Confederation College graduates as forestry profes- sionals and members of the CIF, and look forward to annual ring presentation ceremonies in the future."

Confederation College's Forestry Technician program moved from Lakehead University five years ago and is modeled on the original university diploma program. There are strong ties to the University's Faculty of Forestry and the Forest Environment, with 10\% of Confederation graduates moving on to take related degree programs as they continue their forestry education. For more information please visit the Confederation College Web site: www.confederationc.on.ca/forestry.

Submitted by

Prof. Frances E. Bennett-Sutton, R.P.F. Forestry and Environmental Technician Program Confederation College

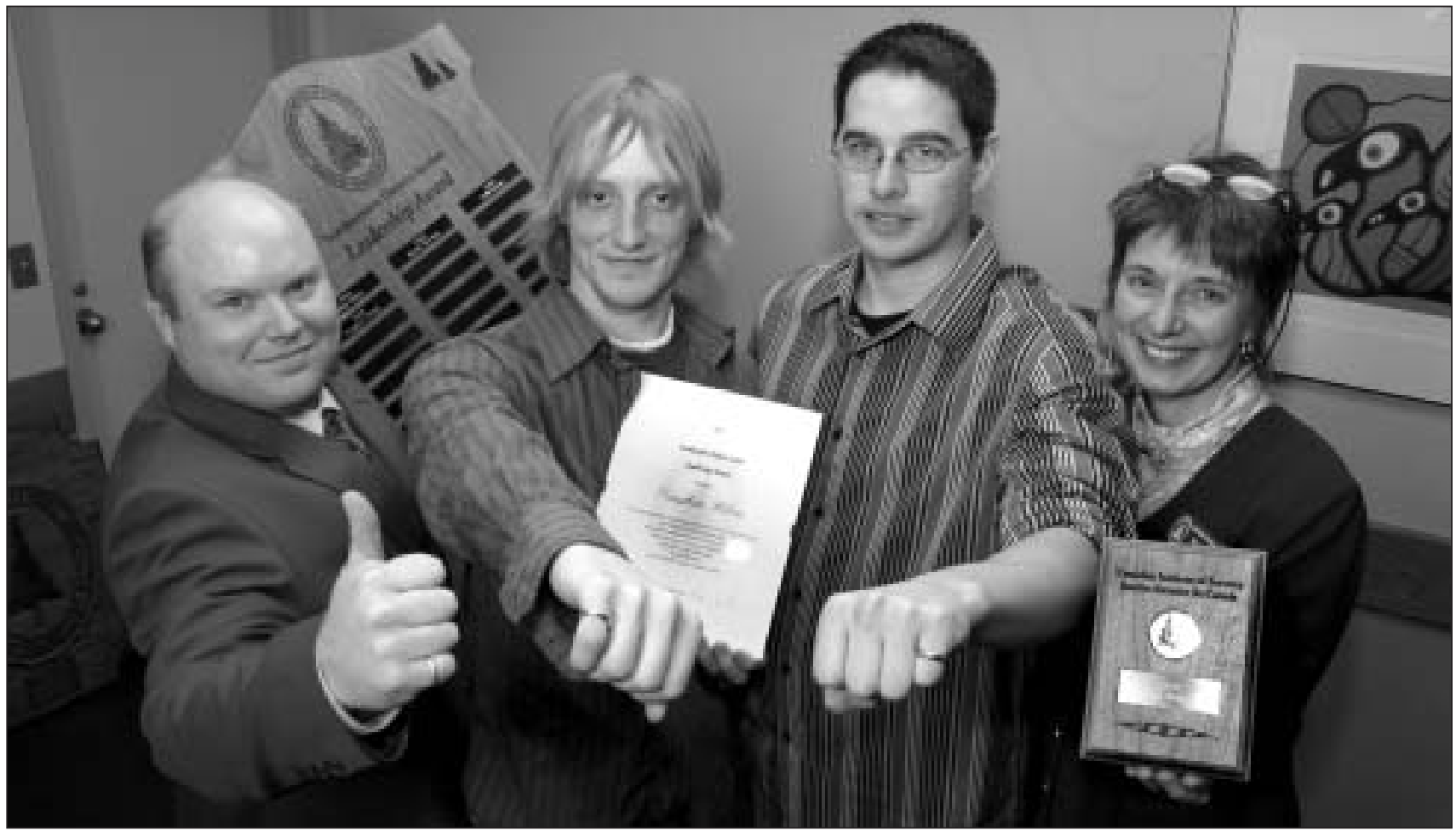

(L to R) Kevin Ride, Director of the Northwestern Ontario Section, Vaughan Wilson, CIF Leadership Award Recipient, Tyson Williams, CIF Gold Medal Recipient, Dr. Nancy Luckai, Chair of the Northwestern Ontario Section. 


\section{Malaspina University-College}

tefan Borge is this year's Gold Medal winner. Stefan is a second-year student in the Forest Resources Technology diploma program. Prior to his enrollment in forestry Stefan had been employed by the Canadian Coast Guard and earlier by the Strathcona Park Lodge as an outdoor education leader. During his time at Malaspina Stefan demonstrated very high standards in both field and academic aspects of his studies. A hard-working and dedicated person he has been a great help to his fellow students. We thank the Canadian Institute of Forestry for recognizing Stefan's work ethic and dedication with the Gold Medal.

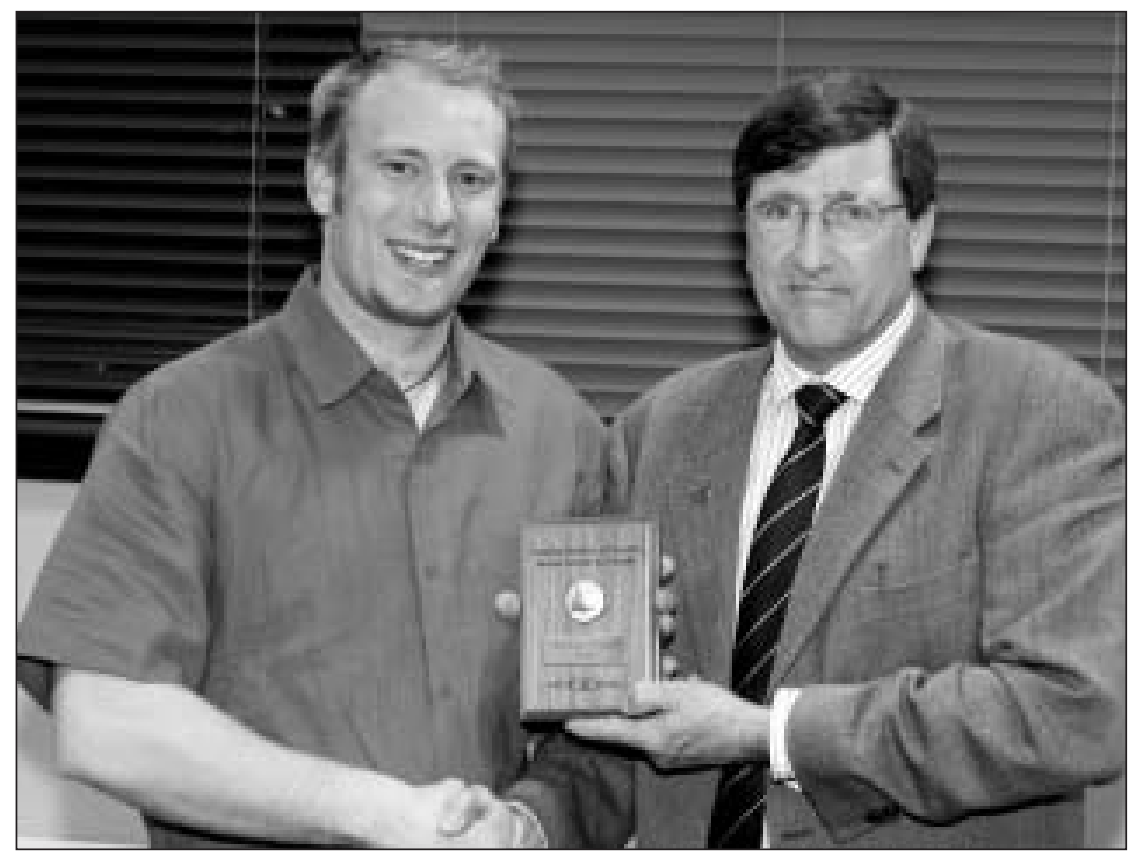

Michel Vallee, CIF Chair and Director for the Vancouver Island Section and Stefan Borge.

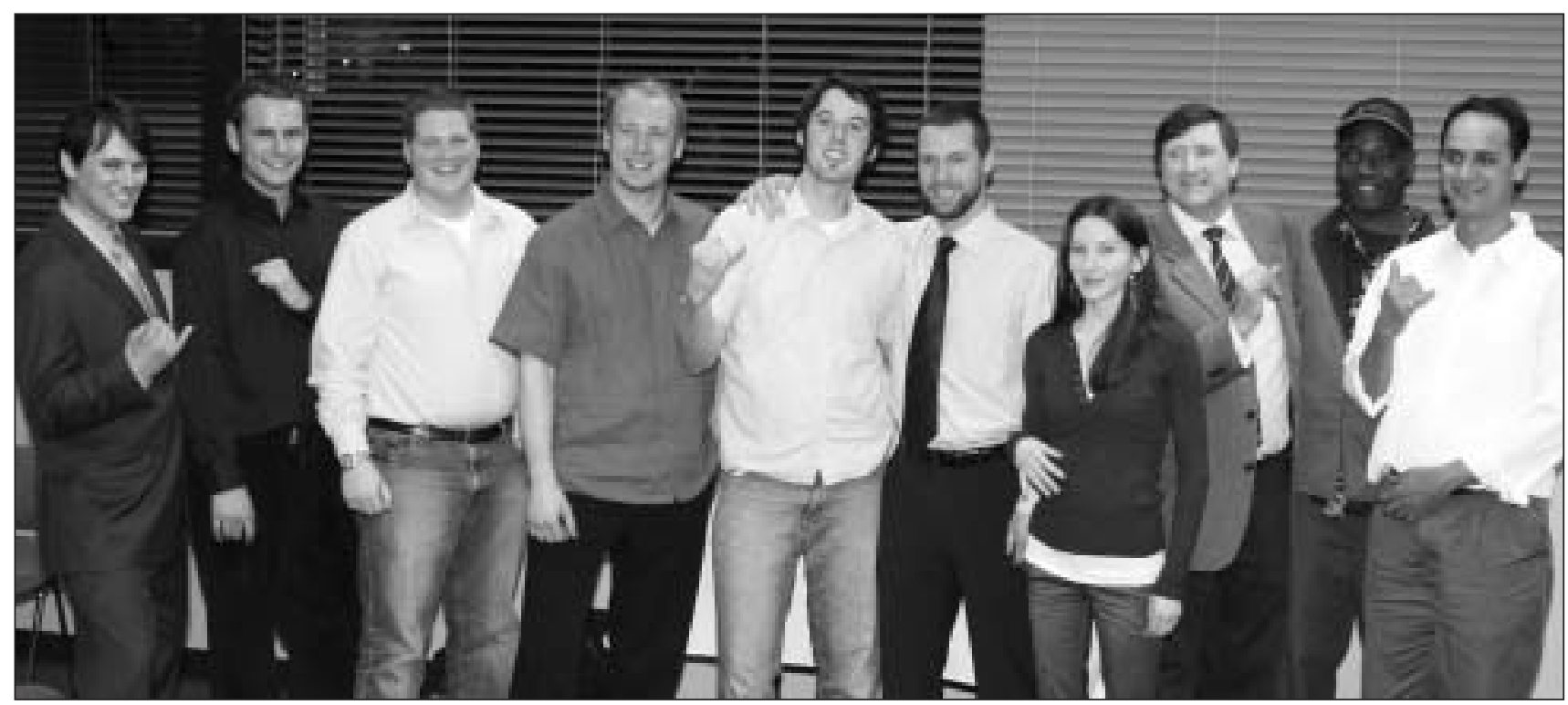

Malaspina CIF Silver Ring recipients.

\section{Forestry Careers and Employment Your Internet Gateway to Forestry and Forest Products}

The Forestry Careers and Employment Bulletin Board lists job openings in every branch of Canada's forest sectorin woodlands, in manufacturing, in sales, in research and education. If you are looking for a job, check out our current listings below. Bookmark this page as we are constantly posting new opportunities.

This is a service open only to Canadian citizens, landed immigrants in Canada, or to those would otherwise qualify to work in Canada.

http://www.canadian-forests.com/job.html 


\section{Nipissing University}

ubbing Shoulders with the I Experts: A Student's Perspective on Nipissing University's Red Oak Workshop

Early in March forest researchers and managers gathered in North Bay, Ontario at Nipissing University's "Red Oak Workshop" to share their knowledge and recent findings. The keynote speaker was senior researcher Dan Dey of the United States Department of Agriculture's Forest Service, Northern Research Station in Missouri.

Peter Nosko, a Nipissing University biologist who supervises the Plant Ecology Research Lab (PERL), and Jeff Dech, a NSERC Industrial Research and Development Fellow working with PERL and the Forestry Research Partnership (FRP), organized the workshop. As fourth-year biology students and budding red oak researchers working in PERL on our Honours thesis projects, we were excited about the unique opportunity to participate in this event; not only to take our turn on the registration desk, but also to present the research that we had been working on over the previous year.
In recent decades, red oak forests have not been regenerating adequately, thereby causing a decline throughout the North American range for this species. The reduction of red oak regeneration could present serious problems for wildlife species, as oak is an important source of food and shelter for a variety of organisms. Furthermore, red oak is a relatively high-value timber species for the forest industry in eastern North America, making regeneration critical.

Despite the bad weather, which accompanied Dey from Missouri, the workshop was a great success. Spectators included representatives from Nipissing and Laurentian Universities, the Canadian Institute of Forestry, the Ontario Ministry of Natural Resources, Southern Science and Information Section (SSIS), the FRP and Nipissing Forest Resource Management Inc., as well as a host of community members who came to learn about red oak and support friends and family.
The workshop also attracted the interest of students such as Kelly Major who will begin researching pine-oak co-management for his forth-year thesis this summer. Major was enthusiastic about the opportunity to hear from experts and gain some background on his project and commented, "It was wonderful to meet and learn from professionals from industry and the scientific community. It makes me excited about the direction I will be taking with my research in the Plant Ecology Research Lab."

Those who were unable to make it due to the storm, such as faculty members and graduate students from the

Red oak forests have not been regenerating adequately, thereby causing a decline throughout the North American range for this species. The reduction of red oak regeneration could present serious problems for wildlife species, as oak is an important source of food and shelter for a variety of organisms.

Faculty of Forestry at the University of Toronto, were able to see the workshop on an Internet webcast feed. The event was also covered by the CTV News and

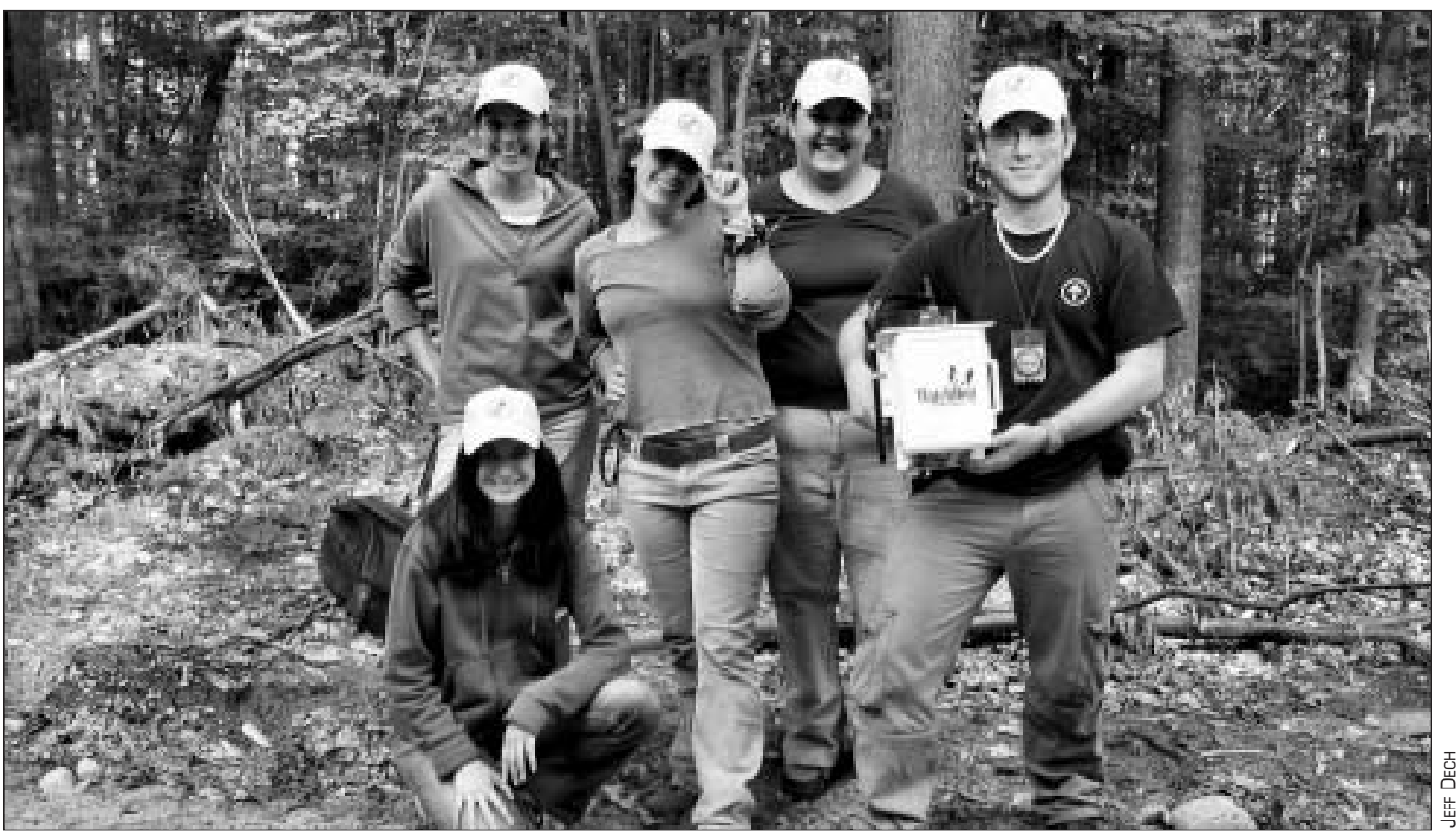

Nipissing University students (left-right: Tara Diebolt, Nicole Irene Quint, Caitlin Langlois, Lisa Robinson and Kelly Major, at the Red Oak Research Site in Redbridge Ontario, 
$\mathrm{CBC}$ radio. The workshop began with an overview on red oak in Ontario forests. Al Stinson of the Ministry of Natural Resources started off the first session with a presentation on the status of red oak research within the FRP. He was followed by Andrée Morneault (OMNR, SSI), Bill Parker (Ontario Forest Research Instititute) and Tom MacLean (Nipissing Forest Resource Management Inc.). These experts discussed red oak ecology, silviculture and management in central Ontario.

Session two consisted of student presentations on current projects at the Phelps Township Red Oak Regeneration Site near Redbridge, Ontario. These studies are part of a new direction in plant ecology research at Nipissing University that arose from the collaboration between Peter Nosko and Jeff Dech. Collectively, the student research explored responses in different growth stages of red oak and its maple competitors, to various partial harvest treatments that had been installed at the Phelps research site. Nicole Quint began the discussion at the seed level, speaking about the physical and chemical effects of leaf litter on germination and seedling recruitment. Next, Nick Roscoe compared the production of sprouts by oak and maple stumps under different degrees of canopy closure. Tara Diebolt then focused on how harvest treatments influence the ability of oak to produce phenolic compounds as a chemical defence against herbivores. Caitlin Langlois discussed seed predation and explored possible distance-dependent patterns in seedling recruitment. The session concluded with Lisa Robinson's presentation on plant community composition in red oak stands and how specific harvest treatments affect the growth and abundance of oak and maples in the understorey.

We were thrilled to have the opportunity to make these presentations and our studies seemed to generate much interest and many encouraging comments from workshop participants. Lisa Robinson summed up our sentiments with her comment, "Presenting our findings to industry, government and university researchers was a positive experience that allowed us an opportunity to meet with and receive feedback from forestry experts. While it's not surprising to learn that so much more research needs to be done, it was great to be a part of such a distinguished group of experts."

The final session offered various perspectives on red oak management. The first presentation by Brian Naylor (OMNR, SSIS) provided a detailed view of the importance of red oak to wildlife. The session continued with an enthusiastic (and at times theatrical) presentation by Dave Deugo (OMNR) on the history of red oak research and management in Ontario. This included "hightech" timeline diagrams outlining the decades of research undertaken by Dave and his colleagues. The evening concluded with the keynote address by Dan Dey. Dey's research focuses on evaluating silvicultural practices for sustaining and restoring oak and oak-pine forests. Dey specializes in solving forest regeneration and afforestation problems as well as examining fire regimes in oak-pine dominated ecosystems throughout the
Midwest and Great Lakes Regions. Prior to his current position with the USDA Forest Service, Dey worked at the Ontario Forest Research Institute as part of a large OMNR research team, many members of which were in attendance. Dey shared his expertise in ecology and management strategies for sustainable red oak regeneration with an appreciative audience. These and other strategies are currently being studied at the Phelps research site. Dey was enthusiastic about the conference, commenting "It was great to come back to Ontario, to have a reunion with good friends that I worked with on red oak regeneration and other forestry problems, and to get caught up on the progress being made in forest research. I was delighted to see the interest in red oak ecology and silviculture being led by Drs. Nosko and Dech, and was impressed with the high quality of work being done by the students in that program."

We never imagined as undergraduate students that we could make such a meaningful contribution and that we would be so welcomed by the large team of government, industry and university researchers who are attempting to solve an important ecological problem.

Caitlin Langlois and Nicole Irene Quint Plant Ecology Research Lab, Nipissing University

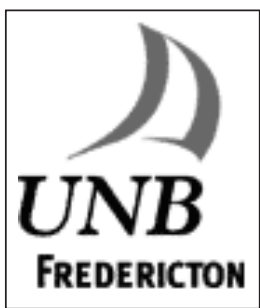

\section{University of New Brunswick}

R ecent Research

Dr. Mark Roberts recently published a paper titled: A conceptual model to characterize disturbance severity in forest harvests in Forest Ecology and Management. It was published with several others as part of a special issue based on organized oral symposium papers at the Ecological Society of America meeting in Montreal in August 2005. The title of the session was "Understory and epiphytic vegetation as indicators of the ecological integrity of managed forests." (reference: Roberts, M.R. 2007. A con- ceptual model to characterize disturbance severity in forest harvests. For. Ecol. Manage. 242: 58-64)

In January, Dr. Tom Beckley gave a presentation titled "Social Sustainability, Stewardship and Survival" at UBC as part of the Distinguished Lecture Series of the British Columbia Forum on Forest Economics and Policy (see www.bc-forum.org/ for details). In March, Dr. Beckley gave a presentation at a panel session on the past, present and future of the forest sector in New Brunswick sponsored by the New
Brunswick Federation of Woodlot Owners. The title of the talk was "The Current Crisis and Strategies for a Better Future."

Dr. Beckley is currently involved with a research team from the Canadian Forest Service (Dr. Solange Nadeau, PI, Dr. Bonita McFarlane) and Université de Moncton (Dr. Stephen Wyatt) in a survey research project on $\mathrm{New}$ Brunswick resident's attitudes and values toward Crown provincial forests. Dr. Beckley recently received two small research grants-one from the New 
Brunswick Department of Natural Resources to conduct a survey of local stakeholder committee members for the Class II Protected Natural Areas, and a grant from the New Brunswick Innovation Foundation to examine how the development of the bio-energy industry might affect woodlot owners in the province.

Dr. Beckley was recently successful in applying for three years of SSHRC funding to study landowner ethics and stewardship and how these relate to private property rights for forest landowners in New Brunswick, Maine, Quebec and Sweden. The title of the project is "Private Property and Public Goods: The Dynamic Tension Between Ownership and Stewardship for Private Forest Owners."

\section{International Forestry Studies visit Indiana}

Four students and two professors visited the state of Indiana recently to learn about forestry research and practices in the Midwest region of the United States. Harrison Blizzard, Hugo Laperle, Ryan McIntyre, Andrew Oliver, Dr. John Kershaw and Dr. Evelyn Richards visited the state from March 1 to 12 . Indiana is very different than New Brunswick in terms of forestry: only $20 \%$ of the land-base is forestland, $83 \%$ of the land is privately owned in small fragmented blocks (average $10 \mathrm{ha}$ ), and the species composition is $95 \%$ hardwoods. They learned about c u t $\mathrm{t}$ in g - e d g e research conducted at Purdue University and Indiana University, as well as at the Martel Research Forest where walnut plantations established by grafting are studied for growth productivity. They also visited Pine Hills Nature Reserve, Morgan Monroe State Park, Turkey Run State Park, Hoosier National Forest, Pioneer Mothers Memorial Forest - a forest believed to have never been harvested before-and D.R. Webb Veneer (a leading company in the veneer industry).

\section{CIF Gold Medal Winner}

The CIF Gold Medal recipient for 2007 is Ryan McIntyre. Ryan grew up in Digby, Nova Scotia. While at university, he was involved with the UNB Woodsmen team, competing at lumberjack competitions around eastern Canada and in the eastern United States. As well as a full-time competitor, Ryan was also

\section{Northern Alberta Institute of Technology (N.A.I.T.)}

I city girl, Cassie Corbin stumbled into forestry straight out of Ross Sheppard High School thanks to the Junior Forest Ranger Program put on by Sustainable Resource Development. She spent her summer learning about the various sides of forestry through mill tours, tree planting, prescribed burns, and fire lookout tours. The dynamic and outdoor aspects of the job attracted her so she decided to explore the opportunities that forestry provided.

In the summer of 2001 and 2002, Cassie worked as a Non-Native Vegetation Supervisor for Parks Canada in Jasper National Park. Here her interest was peaked by the fire aspect of forestry during some prescribed burns she assisted on. Cassie followed up that interest over the next three summers (2003-2005) by working on a Helitack wildland firefighting crew for the Province of Alberta. It was based on this experience in Smoky Wildfire
Management Area that she decided to pursue forestry full-time and was recommended to the N.A.I.T. Forest Technology program.

During her school years, Cassie kept herself busy both with academics and extra-curricular activities. She was involved with the Forest Technology Club at N.A.I.T. as Secretary/Treasurer and helped with Bull of the Woods and the Graduation Banquet. Outside of school she was principle flute in the yearly production of The Singing Christmas Tree, and for Scouts Canada, she was a Scout leader for the Scout troop and Vice President of the Rover Crew.

With the completion of her Diploma, Cassie was hired by the Forest Protection Division of Sustainable Resource Development as a Wildfire Ranger in Grande Prairie, Alberta. She's currently still learning the ropes of her position, but already has been involved in wildfire

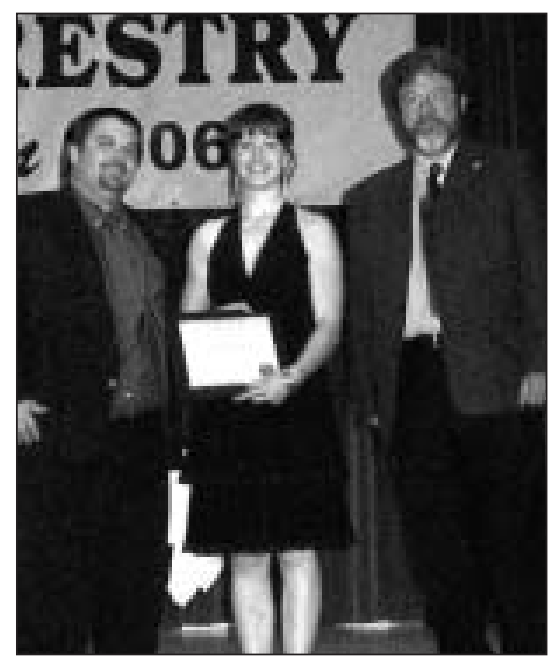

Cassie Corbin, २0०६ CIF Gold Medal recipient.

suppression activities, public education programs, facilities maintenance, issuing orders to remove and wildfire investigations. Her future aspiration is to become an Ignition Specialist. 
The 2006 recipient of the Canadian Institute of Forestry Gold Medal Award, for the Forestry Technician Program at Algonquin College in the Ottawa Valley, was Andrea Coote. Andrea graduated with Honours and made the Dean's List in all semesters.

During the college year, Andrea was the team captain of the College Loggersports' Jack and Jill team and also did fundraising for their meets and demonstrations at local carnivals and fairs. She was our softball team's cocaptain, which made the finals at the Algonquin College Student Association tournament.

She was this year's class vicerepresentative, and was a note taker for a student with special needs. As well, she found time to volunteer for several functions. She helped construct a portage along the Bonnechere River in Algonquin Park; aided in the expansion of Pansy Patch Park in Pembroke; and tended the plantations at the Kiwanis Club Tree Farm in Beachburg. Andrea assisted in the Renfrew County Annual Woodlot Conference and volunteered in the Canada Blooms Festival and the Toronto and Region Conservation Authority Peel Water Festival.

Upon graduation, Andrea has gained employment as a Mountain Pine Beetle Technician with the Alberta Sustainable Resource Development.

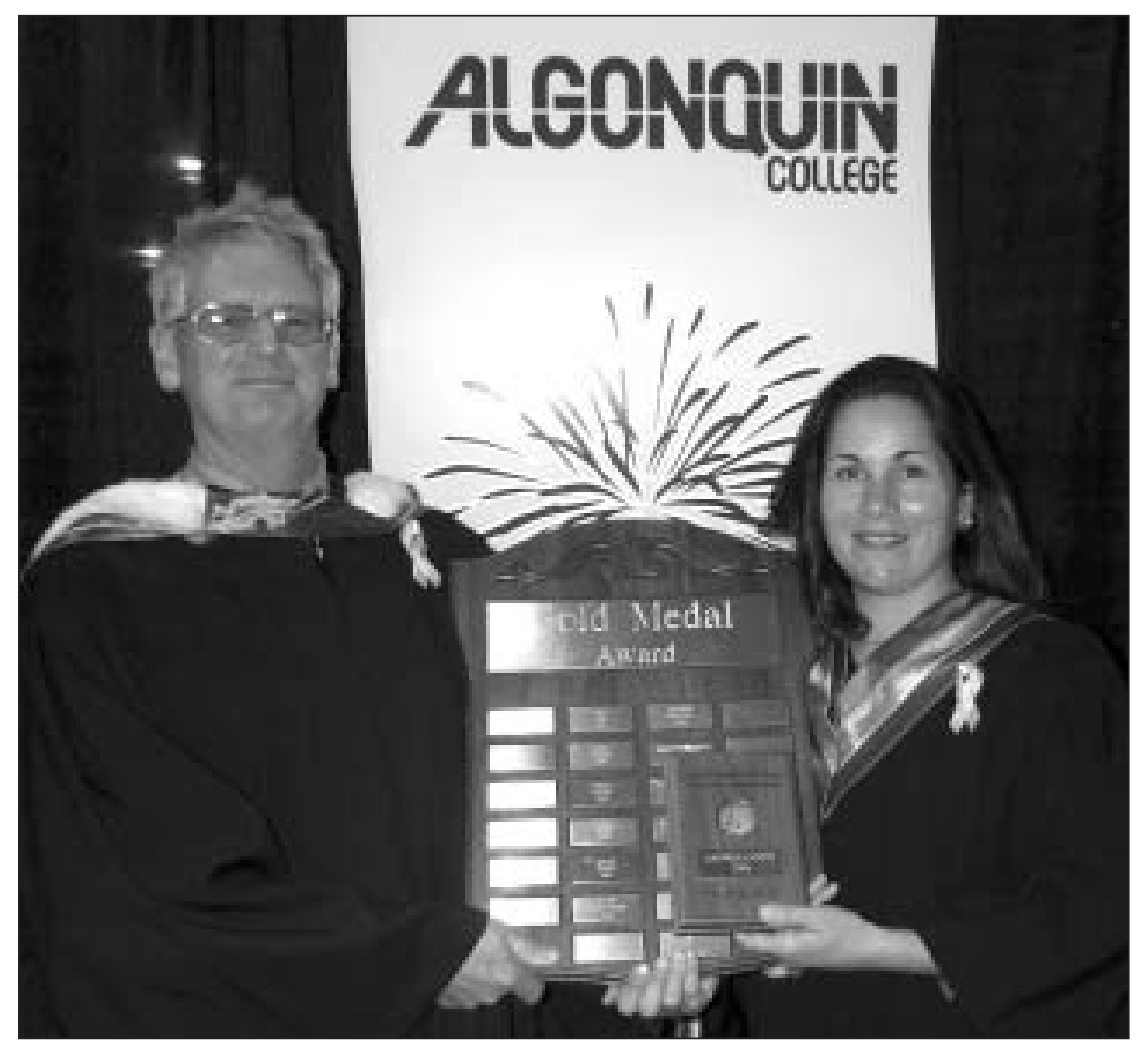

Frank Knaapen, Algonquin Section Councilor, and Andrea Coote at Convocation, २००६.

"My one year at Algonquin has been very rewarding and exciting. Never did I realize that there is so much to learn about forestry, the environment and nature. The professors and all those hands-on field exercises and tests have trained me well and instilled a confidence in me that I can make a difference. My classmates were all supportive and we sure did have a great time."

"As I tracked the steady impact of environmental and then ecological objectives on forest management, I came to the conclusion that this was not a mere question of policy objectives, in which one could weigh one set of policies against another, but was rooted much more deeply in the cultural attitudes of the participants, which shaped strongly felt perspectives. Nor was it a matter of tracking a social movement with its strategies of organization and advocacy, whereby one could readily argue, as the commodity advocates did, that the issues were generated by the need for organizational enhancement, rather than being 'real' issues. The differences lay deeper, rooted in the participants' values as to the meaning of forests."

Samuel P. HaYs; WARS in the WOODS AnNounCed IN THE January/February ChroniCLE 